\title{
Nanoparticles: A Novel Approach for Sustainable Agro-productivity
}

\author{
Alaa El-Dein Omara ${ }^{1}$, Tamer Elsakhawy ${ }^{1}$, Tarek Alshaal ${ }^{2,3}$, Hassan El-Ramady ${ }^{2,3}$, \\ Zoltán Kovács ${ }^{3}$ and Miklós Fári ${ }^{3}$ \\ ${ }^{1}$ Agriculture Microbiology Dept., Soil, Water and Environment Research Institute \\ (SWERI), Sakha Agricultural Research Station, Agriculture Research Center (ARC), \\ Egypt. \\ ${ }^{2}$ Soil and Water Dept., Faculty of Agriculture, Kafrelsheikh Univ., Egypt. \\ ${ }^{3}$ Department of Agricultural Botany, Plant Physiology and Biotechnology, University \\ of Debrecen, Egyetem ter 1, Debrecen 4032, Hungary.
}

\begin{abstract}
$\mathbf{T}$ HE GLOBAL agricultural production suffers from many problems and challenges including climate change, natural resources depletion, environmental pollution, soil degradation, etc. Hence, the global security of this vital sector definitely will be threaten including water security, soil security, energy security, food security, etc. Day by day, several attempts already have been conducted in seeking of the humanity for suitable and sustainable solutions to overcome these previous problems. Nanotechnology was and still one of the most important solutions, which will help us to overcome these problems. So, several nanomaterials have been successfully used in many agro-production fields including nanofertilizers, nanopesticides, nanoremediation, nanobiosensors as well as using of nanoparticles in agri-food production. These nanomaterials can help the agro-production to exploit the natural resources in more sustainable manner and to minimize the agro-wastes. Therefore, regulations for more safety in nanomaterials utilization for agro-production should be starting from the handling for seed germination till the handling for postharvest of agricultural products. Several investigations have been proved the importance of nanomaterials in global securities, the agro-production through the nano-agro-chemicals, management of the agro-wastes, etc. Therefore, this review will highlight new insights and novel approaches for using nanomaterials for sustainable agro-productivity. It will also include the impact of nanomaterials on the agro-environement and the enhanced productivity in frame of sustainability.
\end{abstract}

Keywords: Nanomaterials; Sustainable; Water security; Soil security; Nanofertilizers; Agroproduction; Nanoremediator.

\section{Introduction}

Due to the limitation of water and arable land resources, an urgent need is requested to increase effective use of these resources as well as minimize the agro-ecology damage by using the effective modern technologies like nanotechnology (Manjunatha et al. 2016). Several applications of nanotechnologies can be addressed in the developing countries including production, conversion and storage energy (like CNT storage of H; Zhang et al. 2014(a or b); Li and Sun 2016; Liu et al. 2017), enhancement of the agricultural productivity (like herbicide delivery; Pandey et al. 2016; Chhipa and Joshi 2016), water treatment and remediation (like nano-membranes; Toli et al. 2016; Polloni-Silva et al. 2017), diagnosis and screening of diseases (Wang et al. 2016; Mignani et al. 2017), delivery systems of drugs (like nanocapsules; Nawaz and Wong 2017; Wang et al. 2017), processing, coating, packaging and storage of foods (Carbone et al. 2016; Sarkar et al. 2016; Chalco-Sandoval et al. 2017), remediation of air pollution (like nano-catalysts; Kuppusamy et al. 2016), durability of construction (Balapour et al. 2017; Fallah and Nematzadeh 2017), monitoring

"Corresponding author e-mail: alaa.omara@yahoo.com

DOI: $10.21608 / J E N V B S .2019 .7478 .1050$

C2019 National Information and Documentation Center (NIDOC) 
of health (like sensors; Nag-Chowdhury et al. 2016), detection, control of vector and pests (like sensors and pesticides; Chhipa et al. 2016; Dubey and Mailapalli 2016; Manjunatha et al. 2016).

Serious and terrible threats face the world including the global security resulting from the continuous global changes. This global security includes different security types such as water security (Gohar and Cashman 2016; Kang et al. 2017; Malekian et al. 2017; Zhang and Vesselinov 2017), soil security (Koch et al. 2012 2013; Koch 2017), food security (Gohar and Cashman 2016; Kang et al. 2017; Zhang and Vesselinov 2017), energy security (Markovska et al. 2016; Zhang and Vesselinov 2017), environment security (Markovska et al. 2016; Kang et al. 2017), communication security (Alexiou et al. 2016; Gandotra et al. 2017), information security (Spanos and Angelis 2016; Han et al. 2017), etc. The sustainable agro-production mainly depends on many mentioned securities including soil, water, energy and food security. Furthermore, there is closed links among these securities such as food, water, soil and energy security, where the agro-food production and its security need the integration among all these securities. It is worth mentioning that, nanotechnology applications can be used to achieve these previous securities (Siddiqui et al. 2015; Belal and El-Ramady 2016; Dasgupta et al. 2016; Dubey et al. 2016; Kole et al. 2016; Shalaby et al. 2016; Rai and da Silva 2017).

Concerning the applications of nanotechnology in agriculture sector, it thought that nanotechnology will totally revolutionize it (Singh and Prasad 2016). This nanotechnology has the ability to penetrate different agricultural fields including treatment and detection of plant diseases (Park et al. 2006; Al-Samarrai 2012; Servin et al. 2015; Álvarez et al. 2016; Wang et al. 2016; Mignani et al. 2017; Ray et al. 2017), using as sensors (Fryxell and Cao 2007; Otles and Yalcin 2010; Rai et al. 2012; Farrell et al. 2013; Ansari et al. 2016; Chhipa and Joshi 2016; Dubey and Mailapalli 2016; Jyoti and Tomar 2016; Purkayastha and Manhar 2016; Bäcker et al. 2017; Bazin et al. 2017; Lee et al. 2017; Ray et al. 2017; Saylan et al. 2017),( Only recent references are sufficient) nanofertilizers (Naderi and DaneshShahraki 2013; Tarafdar et al. 2014; Dubey and Mailapalli 2016; Chhipa 2016; Chhipa and Joshi 2016), nanopesticides (Kah et al. 2013, 2014; Kah and Hofmann 2014; Dubey and Mailapalli 2016;
Chhipa 2016; Chhipa and Joshi 2016; Pandey et al. 2016; Zhao et al. 2016; Balaure et al. 2017; Jacques et al. 2017), and using in gene transfer as smart delivery systems (Peters et al. 2016; Singh and Prasad 2016). The over application of nanomaterials in agriculture leads to the negative effects representing in the toxic action of these nanomaterials for the agroecosystems (Holden et al. 2013; Hong et al. 2013; García-Gómez et al. 2015; Belal and El-Ramady 2016; Dwivedi et al. 2016; El-Temsah et 2016; Hegde et al. 2016; $\mathrm{Hu}$ et al. 2016; Singh and Prasad 2016; Guo et al. 2017).

Nearly all agricultural practices and production may be touched or penetrated by the nanotechnological sciences. So, several agroproducts could not be only fabricated using nanomaterials but also a huge amount of agrowastes can be managed using these nanomaterials (Dwivedi et al. 2016; Panpatte et al. 2016; Peters et al. 2016; Adebisi et al. 2017; Patil et al. 2017). Hence, great challenges have been created seeking for the sustainability of agro-production including soil security, water, security, energy security, food security, reduction of poverty and improvement of human public health (Ditta et al. 2015; Gupta and Verma 2015; Bello et al. 2016; De La Cueva Bueno et al. 2017; Nuhoff-Isakhanyan et al. 2017). Therefore, many risks have been resulted from this using nanomaterials in agro-production and hence safety approaches should be regulated (Hegde et al. 2016; Mattsson and Simkó 2016; Pandey et al. 2016; Servin and White 2016; Syberg and Hansen 2016; Yang et al. 2016; de Lourdes Oshiro et al. 2017). Although these nanoparticles may have the ability in conservation of both water and lands through certain applied concentrations, they substantially should also sustain or conserve the environment (Chen and Yada 2011; Prasad et al. 2012; Ditta et al. 2015; Bello et al. 2016; Cecchin et al. 2016; Antunes et al. 2017; De La Cueva Bueno et al. 2017). Therefore, this chapter will focus on different applications of nanoparticles in a sustainable agro-production including nanoagrochemicals, nanobiosensors and nano-agrofood production. The application of nanoparticles in the management of agro-wastes and the risks as well as safety of these nanoparticles will be also highlighted.

\section{Nanoparticles for sustainable agro-production}

Agriculture sector directly or indirectly is the backbone of most developing countries and it has been one of the primary drivers of economy. 
Therefore, it is important to recognize the global agro-production problems such as changing climate, sustainable use of natural resources and environmental issues like runoff and accumulation of pesticides and fertilizers as well as urbanization (Lal et al. 2016; Arodudu et al. 2017; Chen et al. 2017). In addition, the world's population will grow to a reach about to 6-9 billion people by 2050 and it must improve to feed a rapidly growing world population (Chen and Yada 2011; Ditta et al. 2015). Hence, it is necessary to use the modern agricultural technologies such as nanotechnology and nanobiotechnology for sustainable agro-production, which it can be use of nano-sized particles with some unique properties such as thermal, optical, chemical, physical, magnetic and electrical compared to properties of their bulk material (Duràn et al. 2007). On the other hand, complete characterization of nanoparticles (NPs), including shape, surface area, surface chemistry, surface charge, size distribution, crystallinity, porosity, and solubility are poorly understood (Dhawan and Sharma 2010; Anandharamakrishnan 2014; Maskos and Stauber 2017).

Therefore, the topic of nanoparticles could be considered as one of the most important tools in sustainable agro-production by improving the productivity of crops including crops for human consumption and animal feeding as well as reducing pesticide use (Dwivedi et al. 2016; Shalaby et al. 2016; Thakur and Maiti 2016). Furthermore, the application of nanoparticles can help the environment through agro-waste reduction as well as high-value products and pollution control (Hong et al. 2013; Belal and El-Ramady 2016; Bäuerlein et al. 2017). To sum up, the most important parameter that should be considered for characterization of nanoparticles is the size (Madhumitha et al. 2016). Also, it is critical for assessment of the interactions of nanoparticles with living systems (Berhanu et al. 2009; Sayesand Warheit 2009; Warheit 2008; Siddiqui et al. 2015; Kole et al. 2016). To determine the size and other physico-chemical properties of nanoparticles there are many methods and technology such as atomic force microscopy (AFM), scanning electron microscopy (SEM), transmission electron microscopy (TEM), dynamic light scattering (DLS), BrunauerEmmett-Teller (BET), X-ray diffractometer (XRD) and UV-vis spectrophotometer (e.g., Kumar et al. 2011a, b, c; Park et al. 2014; Pu et al. 2015; Madhumitha et al. 2016).
Therefore, it could be sustained the agricultural production using different nanomaterials and nanoparticles. This point of view has been explained in details in many studies such as Ditta et al. (2015), Belal and El-Ramady (2016), Chhipa and Joshi (2016), Chhipa (2016), Dubey and Mailapalli (2016), Dwivedi et al. (2016), Panpatte et al. (2016), Shalaby et al. (2016), etc. Hence, the sustainable agricultural production using different nanomaterials can be performed in different natural resources including plants (Siddiqui et al. 2015; Kole et al. 2016; Dubey et al. 2016), water (Dasgupta et al. 2016), soil (Belal and El-Ramady 2016; Shalaby et al. 2016), energy (Rai and da Silva 2017), etc. Furthermore, the depletion or over-consumption of these previous resources can be considered a great threat to the sustainability of the agricultural activities. Therefore, it should be focused on the security of these previous resources (water security, soil security, energy security, food security, environment security, etc.) in frame of the sustainability of nanomaterials.

\section{Nanoparticles and water security}

Due to several challenges facing the humanity, there is a crucial need for the green nanotechnology to overcome these problems. The nanomaterials can provide us with the sustainable natural resources including energy, water, lands, etc (Belal and El-Ramady et al. 2016; Shalaby et al. 2016) and several nanoparticles can be used in sustaining different agricultural fields. Therefore, a new mission for the nanotechnology will be created in our seeking towards the security of the entire environment and its components. There is a growing attention for the agricultural water security due to some threats and hazards related to water including floods, drought, pollution, etc. (Dressler and Kargl 2012; Malekian et al. 2017). It is worth to mention that, the agricultural water security is of utmost importance because the agriculture uses represent about $70 \%$ from the renewable water resources worldwide (Taylor 2015; Malekian et al. 2017). A great pressure will be increased on irrigation systems as well as the agricultural production and its quality due to water security. Therefore, without the consideration of the water availability, any discussion about any agricultural activity will be incomplete (Malekian et al. 2017).

Nanomaterials have been used in treatment of agricultural waste water and remediation of pollution (An and Dong 2015). It was reported that, nano-materials (like nano-iron and nano- $\mathrm{TiO}_{2}$ ) 
have been used in remediation of groundwater and removing of nitrate, perchlorate, trichlorethylene and other pollutants (An and Dong 2015; Georgi et al. 2015; El-Temsah et al. 2016; Hamza et al. 2016; Khalil et al. 2017). Concerning nanoremediation, it is well known that, the nanoremediation process refers to the using of nanomaterials in remediating different environmental compartments including contaminated soils, groundwater, waste water, sediments, etc. (Abhilash et al. 2016; Belal and El-Ramady 2016; Gomes et al. 2016; Gil-Díaz et al. 2016; Kuppusamy et al. 2016; Pulimi and Subramanian 2016; Gil-Díaz et al. 2017). This process includes some techniques in case of wastewater treatment such as metal-based nanoadsorbents (nano- $\mathrm{TiO}_{2}$, nanoiron oxide and nano- $\mathrm{Al}_{2} \mathrm{O}_{3}$ and polymeric nano-adsorbents), nanomembrane filtration techniques (nanocomposite, nano-fiber membranes and thin-film nano-composite membranes) and photocatalysis (Qu et al. 2013; Hamza et al. 2016). Therefore, a further research concerning nanomaterials and the water security is needed including different water issues (proper quantity and quality as well as clean and safe water for all populations). Several factors should be also considered concerning water security ranging from the infrastructural, political, economical, social, financial, and biophysical to the global climate changes. Water security also should include both the top level (the global challenge) to the bottom level (societal value).

\section{Nanoparticles and soil security}

Great environmental challenges face humanity including the security of food, water, energy, climate changes and protection the global biodiversity (Bouma and McBratney 2013). So, several global securities containing environment security, water security, food security and energy security and these securities involves how to provide all population worldwide with safe food, water, energy. Therefore, it could be defined the soil security as reported in the great book: ,Global Soil Security" edited by Field et al. (2017). This definition is based on the the rationale (McBratney et al. 2017), the soil dimensions (Field 2017) including the soil capability (Bouma et al. 2017), the soil condition (Lewis et al. 2017), the soil capital (McCarl 2017), the connectivity (Carré et al. 2017), and finally the codification (Koch 2017) as well as the securitisation (McBratney and Jarrett 2017). Therefore, this section will address the questions raised by the use of nanotechnology and its effects on soil security.
At the same time, there is an urgent need to enhance and sustain the agricultural productivity, mitigation of global climate changes, restoration the soil and water resources quality and improvement of the global biodiversity (Lal 2009; Koch 2017). Also, there are several functions of soil such as (1) biomass production, (2) filteration and transformation of substances and nutrients, (3) acting as a carbon and a biodiversity pools, (4) acting as a physical, cultural environments and source of raw materials, and (5) archiving of the geological and cultural heritage (McBratney et al. 2014). From these previous soil functions, a direct or indirect link between nanomaterials and soil security can be found such as nanomaterials and biodiversity (Macer 2014; Schlich et al. 2016), nanomaterials and biomass production (De and Luque 2016; Ma et al. 2017), nanomaterials and soil holding of water and nutrients (Thul and Sarangi 2015; Belal and El-Ramady 2016; Dwivedi et al. 2016; Pulimi and Subramanian 2016; Servin and White 2016), etc.

\section{Nanoparticles and energy security}

It is well known that, energy is the backbone and the crucial element for different kinds of development for all countries including the social, economical and sustainable fields. Several factors control the energy demand including the growth rate of population, the demographic changes and the income per capita, etc (Shaikh et al. 2016). Therefore, an urgent need for the security of energy should be considered or kept into account and the energy should be addressed with water and the environmental systems in frame of the sustainable development. Several challenges will face the universe concerning the energy security during the $21^{\text {st }}$ century such as advancing the energy technologies (like using nanomaterials), enhancing the energy efficiency and energy savings in buildings and moving towards energy systems based on renewable energy sources (Markovska et al. 2016). Regarding the nanomaterials use for bioenergy and biofuel production, Springer already has published a book entitled ,nanotechnology for bioenergy and biofuel production" edited by Rai and da Silva (2017). This book emphasized that it could be used nanotechnology in production both of the sustainable biofuel and bioenergy. Several nanomaterials can be used as nanocatalysts including nanofiber, nanotubes, metal nanoparticles, nanosheets and others in the production of biofuels (e.g., bioethanol and biodiesel) as reported by Antunes et al. (2017). 
Many applications of nanomaterials in bioenergy and biofuels production have been confirmed including lignocellulosic biomass (de Oliveira et al. 2017), carbon-based nanomaterials in the biofuel cell (Ma et al. 2017), nanomaterials for microalgae-based biofuels (Seo et al. 2017), deoxygenation of nonedible biomass (Lee and Juan 2017), and magnetic nanoparticles for biogas production (Antunes et al. 2017). Therefore, many beneficials for nanomaterials in the biofuel production such as improving of the raw materials and assisting in processes and products developed in the industry of sugarcane. On the other hand, several problems will be generated by using of nanomaterials for the biofuel production. Seeking for a sustainable future of the use of nanomaterials in the biofuel production, a concern nanotoxicity research, governance, regulation and the social perspectives should be developed (de Lourdes Oshiro et al. 2017).

Therefore, it could be concluded that, nanotechnology is a promising field in dealing with the sustainability of different agricultural activities. This sustainable agriculture can be achieved through different applications of nanotechnology including the management and security of the natural resources from water, food, energy, soil, to the entire environment. There is not only a sustainable agro-production without considering the security of all natural resources, but also we can not use the applications of nanotechnology without considering the rules of the sustainability. Hence, great challenges face the agricultural production using the nanomaterials and more attention should be done at all levels from the top to bottom and vis versa. The recent agricultural practices can be improved with help of the nanotechnology by enhancing the conservation and management of cultivated crops.

\section{Nanoparticles in agro- production}

Nanoparticles application to the agroproduction sector is multidisciplinary in nature. Therefore, the use of nanoparticles in agriculture has been touched several topics including nanoagrochemicals, nanofertilizers, nanopesticides and nanosensors as mentioned before (Dwivedi et al. 2016; Panpatte et al. 2016; Servin and White 2016). Also, it must improve the global food production, enhancing its quality and reducing the agro-wastes (Fig. 1). The most

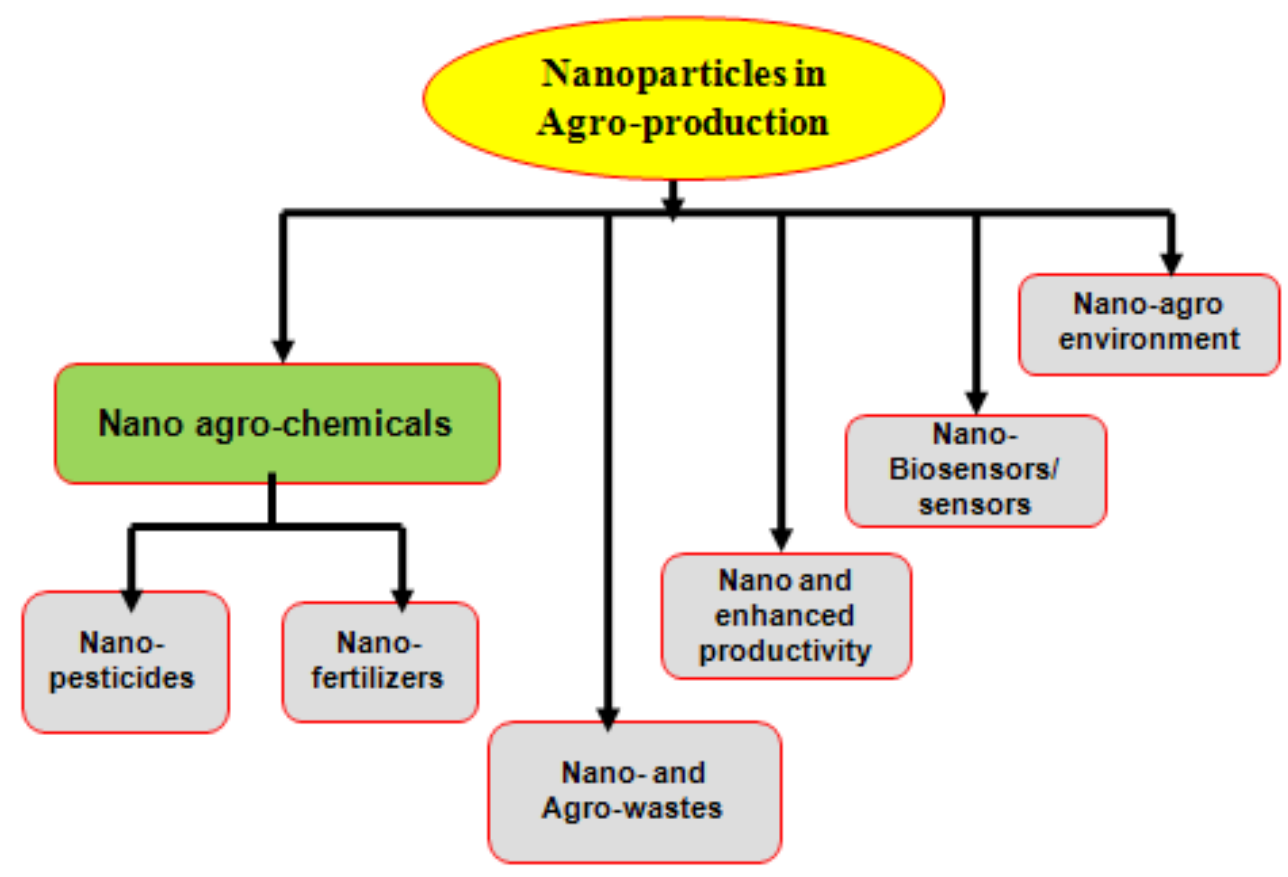

Fig. 1. Multidisciplinary nature of nanoparticles in agro-production including the agrochemicals like fertilizers and pesticides, nanomaterials and agro-wastes, nanosensors, using nanoparticles in enhancing the plant productivity. 
important applications of nanotechnology in agriculture include the monitoring of different environmental stresses (Calanca 2017), delivering different and proper nutrients for plants (Chhipa and Joshi 2016), enhancing the plant protection against pests and diseases (Dubey and Mailapalli 2016), delivering the appropriate pesticides (Chhipa 2016), enhancing the nutritional and quality of yields (Patra et al. 2016) and remediating the contaminated soil and groundwater (Dasgupta et al. 2016; Pulimi and Subramanian 2016; Singh and Prasad 2016). This section includes the application of nanoagrochemicals (nanofertilizers, nanopesticides, soil nano-conditioners, etc.) in increasing the efficiency of agricultural practices.

\section{Nano-agrochemicals}

Food security and nutrition are essential dimensions of sustainable agro-production development. In addition, climatic changes at global level have led to drastic reduction in agroproduction sector as well as sustainable use of natural resources, urbanization and environmental factors (Aouada and de Moura 2015; Panpatte et al. 2016; Pramanik and Pramanik 2016). Over use fertilizers and accumulation of pesticides are the most important problems of modern agriculture. This poses a serious threat to food security of human on this planet. Because of this, modern agricultural require the use of nanoagrochemicals (Sekhon 2014; Campos et al. 2015; Pulimi and Subramanian 2016). The use of nanoagrochemicals applications in the form of nanofertilizers and nanopesticides for plant nutrition and protection is crucial for sustainable agro-production (Mastronardi et al. 2015; Chhipa 2016). It is worth to mention that, the nanoagrochemicals may include nanofertilizers, nanopesticides, soil nano-conditioners, etc.

\section{Nano-fertilizers}

Most of the applied fertilizers are rendered unavailable to plants due to many factors, such as leaching, degradation by hydrolysis, photolysis and decomposition (Belal and El-Ramady 2016; Chhipa 2016). Hence, it is necessary to minimize nutrient losses during fertilization processes and to increase the crop yield through the exploitation of new applications with the help of nanoparticles (Siddiqui et al. 2015; Pulimi and Subramanian 2016; El-Ramady et al. 2017b). Fertilizers play a pivotal role in increasing the agricultural production by up to $35-40 \%$. Therefore, it is very important for plant growth and development.
Application of nanofertilizers for traditional fertilizer is beneficial because these nanofertilizers have the ability to release nutrients into soils steadily and in a controlled way preventing water pollution (Naderi and Danesh-Shahraki 2013; Singh et al. 2015b; Pandey et al. 2016). Because of development and application of nanofertilizers are still at initial stages, further research should be carried out including all crops and edible plants.

Nanofertilizers can be classified into two categories including macro- and micro-nutrient nanofertilizers. Concerning macronutrient nanofertilizers such as $\mathrm{N}, \mathrm{P}, \mathrm{K}, \mathrm{Mg}$ and $\mathrm{Ca}$, they are comprised of one or more elements that are able to provide essential macronutrients to plants (Liu and Lal 2015). The use of macro-nutrient nanofertilizers leads to an increased efficiency of the elements and reduces the toxicity of the soil, to at least reach the negative effects (Naderi and Danesh-Shahraki, 2013). On the other hand, micronutrient nanofertilizers include $\mathrm{Fe}, \mathrm{Mn}$, $\mathrm{Zn}, \mathrm{Cu}$, and Mo among others, whereas these micronutrients are essential elements that are used by plants in small quantities. In nanofertilizers, the nutrients can be used as coated with thin protective polymer film or capsulated inside nanomaterials (Rai et al. 2012). There are a few systemic studies on the effects of applying nutrient nanofertilizers under field conditions (Liu and Lal 2015). Fertilizers formulations of chitosan NPs for controlled release of NPK (Corradini et al. 2010; Hasaneen et al. 2014), hydroxyapatite NPs for the provider of $\mathrm{P}$ nutrients to crops (Sarkar et al. 2015; Das et al. 2016).

Foliar application of nano-Ca and nano-K chelated fertilizers on Ocimum basilicum had beneficial effect on production characteristics of plants (Ghahremani et al. 2014). Calcium phosphate nano gel fertilizer composites were found to increase the germination in Oryza sativa, Arachis hypogea and Amaranthus spinosus plants (Umarani and Mala 2013). Pot studies with foliar spray approach with zinc oxide nanoparticle solution at $20 \mathrm{mg} \mathrm{mL}^{-1}$ on alfalfa, tomato and cucumber plants at the germination stage showed improved growth and biomass production as compared to control plants (Panwar et al. 2012 and de la Rosa et al. 2013; Sekhon 2014; Adhikari et al. 2015, 2016). Therefore, the application of nanofertilizer has several benefits such as it increases the efficiency of the elements, decreases the soil toxicity and reduces the frequency of fertilizer's application. Fertilizer particles can 
be coated with nano-membranes that facilitate the slow and steady release of nutrients (Table 1; Singh and Prasad 2016). Furthermore, nutrients derived from nanoencapsulation or nanofertilzers have some properties like the controlled release of chemical fertilizers regulating plant growth, enhancing target activity and making them effective to crops demand (De Rosa et al. 2010; Nair et al. 2010; Mani and Mondal 2016; El-
Ramady et al. 2017b).

Therefore, it could be concluded that, nanofertilizers have many distinguished properties such as (1) the main dimension of nutrient carrier ranges from $30-40 \mathrm{~nm}$, (2) the nutrient use efficiency of nanofertilizers is high comparing with traditional fertilizers, as well as release of nutrients is slowly and steadily for

\section{TABLE 1. Different effects of nanofertilizers on some agricultural crops.}

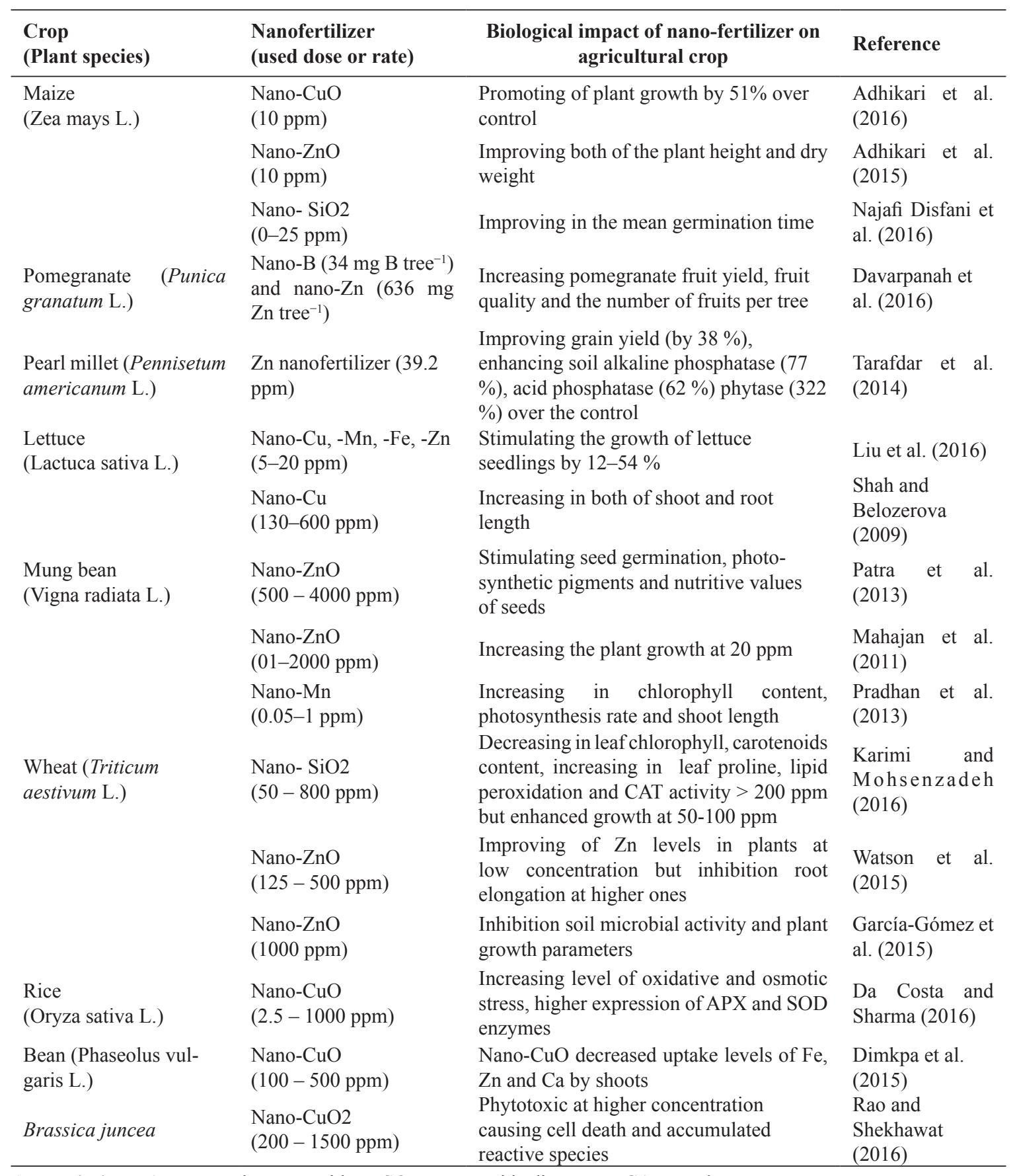

Abbreviations: APX: ascorbate peroxidase; SOD: superoxide dismutase; CAT: catalase 
more than 30 days, (3) the nanofertilizers are easy to synthesize through fortifying nutrients in single or in combinations so, deliver slowly over a long time reducing the loss of nutrients to the environment (Subramanian et al. 2015; Belal and El-Ramady 2016).

\section{Nano-pesticides}

It is well known that, the pesticides are substances used in plant defence against pest organisms. The applied pesticides include fungicides, insecticides, herbicides, nematicides etc. Unsustainable management of our soil resources has been resulted from the use of synthetic pesticides, although several pesticides eliminate the problem of pests (Bhattacharyya et al. 2016). In the modern agricultural, pesticides are commonly used to increase crop yield and efficiency. Therefore, nanopesticides are one of new strategies used to solve the problems of non-nanopesticides (Sasson et al. 2007; Pandey et al. 2016; Petosa et al. 2017). Nanoparticles can be used in the preparation of novel formulations like pesticides, insecticides and insect repellants (Gajbhiye et al. 2009; Fulekar 2010; Vinutha et al. 2013; Chhipa 2016). In the recent research, nano-sized agrochemicals are mostly nano-reformulations of existing fungicides and pesticides (Green and Beestman 2007). Nanopesticides including polymeric nanoparticles, gold nanoparticles, silver ions and iron oxide nanoparticles have been exploited as pesticides. Nanopesticides can offer a way to control delivery of pesticide and achieve higher effects with lower chemical dose (Chhipa and Joshi (2016). Therefore, nanopesticides are generally expected to improve the apparent solubility of poorly soluble active ingredients, and release the active ingredient in a slow manner and protect against premature degradation (Kah et al. 2013, 2014; Kah and Hofmann 2014; Dubey and Mailapalli 2016). Also, it is important to note that some nanopesticides may offer a number of benefits, including increased efficacy, exposure to non-target organisms or the development of resistances and reductions in application rates (Khot et al. 2012; Bhattacharyya et al. 2016; Zhao et al. 2016).

Aspects of nanoparticle, some researchers have various reported about characterization, effect of their characteristics, formulation and their applications in management of plant diseases (Al-Samarrai 2012; Álvarez et al. 2016; Dubey and Mailapalli 2016; Pandey et al. 2016). Some formulations contain nanopesticides within the $100-250 \mathrm{~nm}$ size range that are able to dissolve in water which are more effective than existing ones (Pérez-de-Luque and Rubiales 2009; De et al. 2014; Servin et al. 2015; Servin and White 2016). Other formulations contain uniform suspensions of pesticidal or herbicidal nanoparticles in the range of 200-400 nm such as nanocapsules herbicides can enable effective penetration through cuticles and tissues, allowing to slow and constant release of the active substances. The potential of nanopesticides in pest management as modern approaches of nanotechnology has been reported (Khandelwal et al. 2016; Zhao et al. 2016). It is reported that, silver nanoparticles have received significant attention as a pesticide for agricultural applications (Lamsal et al. 2011; Bhattacharyya et al. 2016). Silver nanoparticles can be inhibited mycelia growth and conidial germination on pumpkins and cucurbits against powdery mildew at $100 \mathrm{mg} \mathrm{kg}^{-1}$. Also, in soda lime glass powder, copper nanoparticles showed efficient antimicrobial activity against fungi and grampositive and gram-negative bacteria (EstebanTejeda et al. 2009). Silica-silver nanoparticles against Botrytis cinerea, Rhizoctonia solani, Calllectotrichum gloeosporioides, Bipolaris sorokiniana and Magnaporthe grisea have been reported by Park et al. (2006) and Jo et al. (2009) as well as against Escherichia coli and Staphylococcus aureus as reported by Priebe et al. (2017).

Using of nano-insecticides and their applications in agriculture have been opened a new field regarding plant protection management. Therefore, nanoencapsulation is currently the most promising technology for protection of host plants against insect pests (Lai et al. 2006; Hussain et al. 2017). With nanoencapsulation techniques, it is possible to step down the chemical release under controlled situations, reducing the current application dosage and improving efficiency (Sastry et al. 2007; Balaji et al. 2017). A novel degradable insecticide involving nanoparticles has been reported (e.g., Loganathan and John 2017; Kailasa and Rohit 2017). Nano-silica has been successfully employed to control a range of agricultural insects/pests as well as ecto-parasites in animals. Such nanoparticles get absorbed into cuticular lipids (which used by insects to prevent death from desiccation) by physical sorption and cause insect death by physical when applied on leaves and stem surfaces (Ulrichs et al. 2005; Bapat et al. 2016). Nano-encapsulated 
pesticides will have the ability to kill targeted insects only, thereby reducing the effective dose when compared to traditional pesticides. Also, significant mortality of two insect pests (Sarocladium oryzae and Rhyzopertha dominica) after 3 days exposure to nano-structured aluminatreated wheat (Stadler et al. 2010). Therefore, it could be concluded that, the nanopesticides can be defined as any formulation includes elements in the nm size range and/or claims novel properties associated with these small size range. These nanopesticides include two main ingredients organic (such as polymers) and inorganic like metal oxides in various forms (Ragaei and Sabry 2014).

\section{Nano-remediators and nano-reclaimants}

The removing of pollutants from soils and waters can be considered one of the most important challenges facing the universe. The remediation of contaminated areas is not only the main target but also the sustainable remediation is an urgent need (El-Ramady et al. 2017a). Therefore, nanoremediation may be considered as a promising strategy in controlling pollution and management using nanomaterials with mediated animal, plants, and microbes (El-Ramady et al. 2017a). Furthermore, nano-remediators of soils such as zero-valent iron nanoparticles (nZVI), iron sulfide $(\mathrm{FeS})$ nanoparticles, iron phosphate nanoparticles, $\mathrm{ZnO}, \mathrm{TiO}_{2}$, carbon nanotubes, fullerenes and bimetallic nano-metals can be used (Rabbani et al. 2016). These nanoparticles have four missions in soil nanoremediation including (1) reducing the soil heavy metal concentration in leachates to acceptable level (Alvarez et al. 2017), (2) immobilization of soil heavy metals (e.g. Cr VI, Pb II, As III and Cd) in polluted soils (Michálková et al. 2016; Rani et al. 2017), (3) remediation the redox potential enhancing the convert of some soil heavy metals (like $\mathrm{Cr}$ VI) to less toxic forms (Boruah et al. 2017) and (4) degradation of organic contaminants (e.g. DDT, chlorinated organic solvents, carbamates, etc) (Abhilash et al. 2016; Saylan et al. 2017).

It is well documented that, nanotechnology can play a great role in managing many stressed regions like salt-affected and marginal lands (Patra et al. 2016). Several approaches may be used in managing these lands including chemical reclamation (a very expensive source) or nanomaterials. These soil nano-reclaimants can effectively create improved soil materials and systems as well as managing these lands using nanoproperties (Patra et al. 2016; Floris et al. 2017). Therefore, it could be used many nanomaterials (nanoreclaimants) in developing and reclamation salt-affected soils including nano gypsum, nanocalcium (Nano- $\mathrm{Ca}^{2+}$ ) and nano-magnesium (nano$\mathrm{Mg}^{2+}$ ) compounds, etc. These nanoreclaimants are more efficient and readily manufacturable as well as enhancement hydraulic characteristics and soil stability (Mukhopadhyay and Kaur 2016; Patra et al. 2016). These nano-reclaimants have several advantages in reclamation the salt-affected soils such as:

1. Improving soil drainage through removing $\mathrm{Na}^{+}$from soil solution and improving soil structure in subsurface and sub soils using nano- $\mathrm{Ca}^{2+}$, nanoferrites as well as biofriendly nanopolymers

2. Replacing $\mathrm{Na}^{+}$by $\mathrm{Ca}^{2+}$ by removing $\mathrm{Na}^{+}$from soil and replacing by nano- $\mathrm{Ca}^{2+}$, nano- $\mathrm{Mg}^{2+}$ and nano- $\mathrm{K}^{+}$

3. Reducing salt concentration in soil solution through enhancement $\mathrm{Na}$ removal, soil stability and hydraulic characteristics using polymeric carriers in nano-reclaimants via clay binding processes

4. Prevention of $\mathrm{Na}_{2} \mathrm{CO}_{3}$ formation through nanomaterials (nanocalcium carbonates, nano- $\mathrm{Ca}^{2+}$, nano- $\mathrm{Mg}^{2+}$, nano- $\mathrm{K}^{+}$and nanoiron oxides may be used in preventing $\mathrm{Na}_{2} \mathrm{CO}_{3}$ formation in soils)

5. Addition of $\mathrm{K}^{+}$or nano- $\mathrm{K}^{+}$in clay minerals like illite can accelerate ion exchange reactions $\left(\mathrm{Ca}^{2+}, \mathrm{Mg}^{2+}\right.$ and $\left.\mathrm{Na}^{+}\right)$to reduce exchangeable sodium saturation (Patra et al. 2016).

\section{Nanobiosensors/ nanosensors}

It is reported that, the sustainable agriculture may support for enhancing crop productivity using nanobiosensors. These nanobiosensors can be effectively used for sensing a wide variety of fertilizers, herbicide, pesticide, insecticide, pathogens, moisture, soil $\mathrm{pH}$, and their controlled use (Rai et al. 2012; Sekhon 2014). The future application of these nano-biosensors recently developed by several authors such as Zhang et al. (2014a, b), Bazin et al. (2017), Bhat et al. (2017), Kurbanoglu et al. (2017), Lee et al. (2017) and Ray et al. (2017). Nanobiosensors are getting applications in different industries other than food and agriculture, but recently many sensors have been developed after considering its importance (Sekhon 2014; Jyoti and Tomar 2016). This technology can provide farmers in 
agro-production sector with better fertilization management, reduction of inputs and better management of time and the environment, thereby increasing productivity in agriculture as well as could help in the efficient use of agricultural natural resources like water, nutrients, chemicals (Farrell et al. 2013; Dasgupta et al. 2015; Ansari et al. 2016). Also, in the field nanobiosensors can detect the presence of plant viruses and other crop pathogens and the level of soil nutrients (Jones 2006; Brock et al. 2011).

For monitoring the impacts of agricultural pollutants on biological and ecological health, some researchers use nanosensors (Ansari et al. 2016). These nanosensors also can use in increasing the crop productivity and reducing land burden, through electrochemically functionalized singlewalled carbon nanotube (SWCNTs) with either metal nanoparticles or metal oxide nanoparticles and metal oxide nanowires and nanotubes for gases such as nitrogen oxides, ammonia, sulfur dioxide, hydrogen sulfide and volatile organics (Wanekaya et al. 2006; Ramnani et al. 2016). Significant contributions in the field of nanobiosensors research, which bionanotechnology has the potential to radically alter the way sensors are designed, constructed and implemented (Al-Garawi et al. 2016; Kök 2016). Biosensor design showed good compatibility between membranes and enzymes without a change of the confirmation of the enzyme molecule and binding always takes place outside the enzyme active centers (Yotova et al. 2013; Bäcker et al. 2017). Therefore, the development of sensors/biosensors depends on specific interactions makes atomic forcespectroscopy (Shuai et al. 2017).

\section{Nanomaterials in agri-food production}

No doubt that the agriculture is the main source for our food. So, a very important book series published by Springer entitled "Nanoscience in Food and Agriculture". This book series already published till now 3 volumes and edited by Eric Lichtfuse and his co-editors. This reflects the potential of three items at the same time including the nanotechnology, food and agriculture. Furthermore, several book chapters have been published within this series regarding the applications of nanotechnology in food and agriculture sectors. These chapters include nanofood processing and packaging (e.g., Brandelli et al. 2016; Kumar et al. 2016; Kuswandi 2016; Purkayastha et al. 2016; Rao and Naidu 2016; Sarkar et al. 2016; Singh et al. 2016), nano- agriculture (Chowdhury et al. 2016; Dasgupta et al. 2016; Kasana et al. 2016; Madhumitha et al. 2016; Pramanik and Pramanik 2016; Shalaby et al. 2016), nanoparticles remediation in soils and water (Belal and El-Ramady 2016; Khan et al. 2016; Prashantha Kumar et al. 2016; Pulimi and Subramanian 2016; Shalaby et al. 2016; Xue et al. 2016), nanobiotechnology (Brandelli et al. 2016; Kasana et al. 2016), etc.

The sustainable technology is considered as one of the greatest challenges facing the European Commission, so a strategy for key enabling technologies (KETs) for Europe has been established by European Commission in (2012). These technologies include (1) nanotechnology, (2) micro- and nano-electronics, (3) industrial biotechnology, (4) advanced materials, (5) photonics and (6) advanced manufacturing technologies (EC 2017). This nanotechnology may offer further innovations in many industrial sectors such as the animal feed, different food processings, different food additives, food contact materials and the primary agricultural production or agri/feed/food (Kah and Hofmann 2014; Sekhon 2014; Peters et al. 2016). As mentioned before, due to the unique propoerties of the nanomaterials (natural and engineered), the nanotechnology is working in characterizing, manufacturing and manipulation of materials at a size range of the nanometer scale. Concerning the engineered nanomaterials used in agri/feed/food, they may be divided into 3 groups including inorganic (nano-silicon dioxide for food processing as anticaking agent metals, nanoselenium for food or health supplements, etc.), organic (e.g., proteins, carbohydrates and fats to build food-grade like polymers or nano-encapsulates and nanoemulsions), and combined materials (e.g., surface modified clays) as reported by Peters et al. (2016).

Nanoparticles for more sustainable agroproduction

The using of nanomaterials in agro-production has several dimensions including the sustainable agro-production, the agro-environmental sustainability of nano-materials, the enhancement of agro-productivity using nanomaterials, the management of agro-wastes using nanomaterials, etc. Without these previous dimensions, it is very difficult to reach to the global security in all sectors including food security, soil security, water security, environment security, etc. Here, we will focus on these previous dimensions in more details. 


\section{Nanoparticles and agro-environment}

Fate and transport of nanoparticles in the environment can consider one of the most important environmental issues (Fig. 2). This fate and transport include the behavior of nanoparticles in different environmental compartments (air, water, soil, sediment, plants, humans, animals, etc.). Concerning the agricultural environment, it is the place in which we can produce our food, feed, fibre and fuel. So, the movement of nanoparticles and their translocation in the terrestrial environments is a crucial issue and should be addressed. Moreover, this behavior of nanoparticles in agroecosystems includes both the positive side (enhancement plant growth, nanoremediation, nanofertilizers, nanopesticides, nano soil conditioners, nanoreclaimants, etc) and the negative side (phytotoxicity, oxidative stress, carcinogenicity, etc). Therefore, several studies have been published concerning the release, transport and toxicity of engineered nanoparticles in the environment (e.g., Terekhovaa and Gladkova 2013; Miseljic and Olsen 2014; Aouada and de Moura 2015; Soni et al. 2015; Schultz et al. 2015; Hedayati et al. 2016; Hegde et al. 2016; Mottier et al. 2017; Tolaymat et al. 2017). Hence, the distribution and transport of nanoparticles in different environments remains an open question.

World food production system depends on the use of traditional pesticides and fertilizers to increase this food production, which leads to several negative effects on the environment (Baker et al. 2013; Wan et al. 2013; Alvarez et al. 2017). Naturally, nanoparticles are contributing immensely to the biogeochemical cycling of carbon, nitrogen, sulfur and phosphorus in the environment. Therefore, nanotechnology represents some new approaches to increase agricultural production and ameliorate of contaminated agro-ecosystem (Powell and Kanarek 2006; Jin et al. 2016; Yang et al. 2016; Formentini et al. 2017; Samarajeewa et al. 2017; Wang et al. 2017). Most nanoparticles are made up of carbon, silicon, metal or metal oxides, which have directly or indirectly adversely effects on the environment and then human health. Furthermore, nanoparticles can be released during their use into the soils and waters as well as increased in different environmental matrixes reflected by an increasing concern over the potential impact (DEFRA 2007; Navarro et al. 2008; Handy et al. 2008; Baun et al. 2008; Soni et al. 2015; Belal and El-Ramady 2016; Yang et al. 2016; Oleszczuk and Kołtowski 2017; Samarajeewa et al. 2017; Vítková et al. 2017).

By active or passive uptake, nanoparticles may enter or transport into the food chain by plants and/or other microorganisms from some different environments. Many factors impact on this translocation of nanoparticles such as

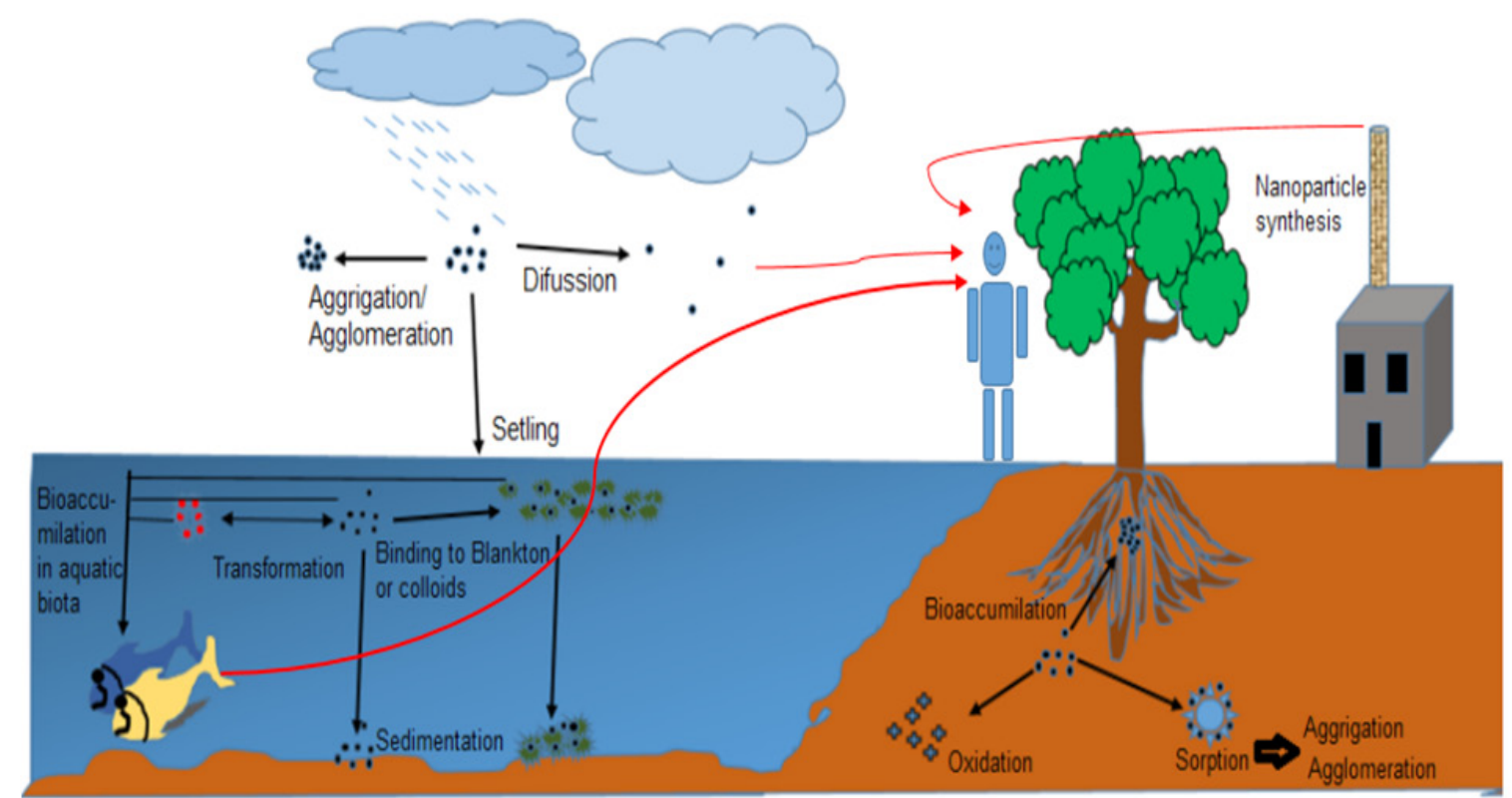

Fig. 2. The fate and behavior of nanoparticles in the environment. This behavior of nanoparticles in agroecosystems includes the positive and the negative effects as well as the release, transport and toxicity of engineered nanoparticles in the terrestrial environments. 
air, soil, water and sediment as well as causing serious alterations in humans and animals (Holbrook et al. 2008; Bouldin et al. 2008; Lin et al. 2009; Soni et al. 2015; Kwak and An 2016). Also, nanoparticles have a potential to carry toxic materials (e.g., lipophilic pollutants and heavy metals) due to large surface areas and a highly reactive nature (Baun et al. 2008; Gil-Díaz et al. 2016, 2017). Other types of nanoparticles may enter into the plants via the root cell walls which have pores with a size ranging from 5 to $20 \mathrm{~nm}$ that allow the passage of small particles (Hischemöller et al. 2009; Cifuentes et al. 2010; Doolette et al. 2015; Tripathi et al. 2017; Zhang et al. 2017). Thereby nanoparticles with sizes smaller than the pore diameter may pass and reach the plasma membrane. Also, some evidences that nanoparticles may enter cells via ion channels and embedded transport carrier proteins and that they may interfere with normal metabolic processes, possibly by the production of reactive oxygen species (Navarro et al. 2008; Tolaymat et al. 2017; Tripathi et al. 2017).

Several researchers reported about the recent applications of nanotechnologies in agroenvironmental studies including the transport and fate of these nanomaterials as well as the beneficial of these applications. The interaction between nanoparticles under soil-plant system can consider one the most important agroenvironmental studies. Therefore, several studies have been focused on these agro-environmental studies including the interactions between nanoparticles under soil-plant systems (Manceau et al. 2008; Anjum et al. 2013; Soni et al. 2015; Belal and El-Ramady 2016; Majumdar et al. 2016; Wu et al. 2016; Tripathi et al. 2017; Zhang et al. 2017), the impacts of applied nanoparticles on the microbial community in soils (Pawlett et al. 2013; Chunjaturas et al. 2014; Sri Sindhura et al. 2014; Simonin and Richaume 2015; Antisari et al. 2016; Pallavi et al. 2016; Read et al. 2016; Samarajeewa et al. 2017), the using of nanoparticles in remediation both of soils and waters (An and Dong 2015; Cecchin et al. 2016; Ghosh et al. 2016; Gonçalves 2016; Zhao et al. 2016; De La Cueva Bueno et al. 2017; El-Ramady et al. 2017a; Fernandes et al. 2017; Kuppusamy et al. 2017), the enhancement of nanofertilizers and nanopesticides for the plant growth and its protection (Davarpanah et al. 2016; Zhao et al. 2016; ElRamady et al. 2017b; Balaji et al. 2017; Petosa et al. 2017), the using of soil nano-reclaimants and nano-conditioners under sustainable agro- production (Patra et al. 2016; Fernandes et al. 2017;), nano-enhancement for crop productivity under stress (Abdel-Haliem et al. 2017; Rizwan et al. 2017; Tassi et al. 2017), etc.

\section{Nanoparticles and enhanced productivity}

Nanotechnology has a great potential, as mentioned before, to increase the global food production, food quality, plant protection, detection of plant and animal diseases, monitoring of plant growth and reduce wastes for sustainable crop productivity (Gruère et al. 2011; Frewer et al. 2011; Biswal et al. 2012; Sonkaria et al. 2012; Prasad et al. 2014; Handford et al. 2015; Ditta et al. 2015; Belal and El-Ramady 2016; Panpatte et al. 2016; Pramanik and Pramanik 2016; Shalaby et al. 2016; Ashoka et al. 2017; Servin et al. 2017). The aim of the use of nanoparticles in the field of agriculture is to enhance the efficiency and sustainability of agricultural productivity by using less inputs and generating less wastes. In world-wide, heavy use of nitrogen and phosphorus fertilizers has become the major anthropogenic factor due to eutrophication problems in freshwater and coastal ecosystems (Conley et al. 2009; Zak et al. 2015; Ge et al. 2016; Wang et al. 2017). Thus, the application of novel nanotechnology in agriculture sector is considered as one of the important approaches in improving crop production and feeding the world by developing and minimize nutrient losses during fertilization processes (Lal 2008; Ditta et al. 2015; Panpatte et al. 2016; Rizwan et al. 2017).

To study the impact of nanoparticles and its roles in enhancing the crop productivity, the interaction of nanoparticles with plants from different sides starting from the seed germination reaching to the harvested crop should be studied (Khan et al. 2017). The applied nanoparticles to cultivated crops may cause various physiological and biochemical changes depending on the properties of these nanoparticles, their concentration and it varies from plant to plant as well as different soil properties (Wang et al. 2016; Tripathi et al. 2017). Nowadays, several reports have been published concerning different impacts of nanoparticles on seed germination, photosynthesis and plant growth with the main target to promote their use of agricultural applications. Recently, Springer also succeeded in publishing some distinguished books such as „Plant Nanotechnology: Principles and Practices" edited by Kole et al. (2016) and "Nanotechnology and Plant Sciences: Nanoparticles and Their Impact on Plants" edited 
by Siddiqui et al. (2015) and the outcoming book this year "Nanomaterials and Plant Potential" edited by Azamal Husen and Muhammad Iqbal beside book about „, Nano Phytotoxicity and Plant Biotechnology".

Concerning nanoparticles and enhanced crop productivity, the crop production can be enhanced through the proper management of growth factors including fertilizers, irrigation, plant protection, cultural practices, etc. The previous practices may be enhanced by using nanomaterials such as nanofertilizers (Mastronardi et al. 2015; Mani and Mondal 2016; Bradfield et al. 2017), nanopesticides (Bhau et al. 2016), nanosensors (Dubey and Mailapalli 2016; Chhipa and Joshi 2016), irrigation management (Singh and Kumar 2016) and nano-farming (Dwivedi et al. 2016). It is worth to mention that, several factors effect on crop productivity including the physiological functions (uptake of nutrients and water, respiration, photosynthesis, transpiration, water relations, etc.) and the environmental conditions (e.g., humidity, precipitation, temperature, biotic/ abiotic stresses) (Maiti and Kumari 2016). Therefore, the agricultural productivity may be controlled by application of nanoparticles for each growth period and all cultural practices. Several publications have been involved in different impacts of applied nanoparticles during the entire plant growth and development periods as follows:

Some studies suggest that metal silver nanoparticles (AgNPs) increased the root length in maize and cabbage plants in comparison with $\mathrm{AgNO}_{3}$ (Pokhrel and Dubey 2013). Also, gold nanoparticles (Au-NPs) increased the number of leaves, plant height, leaf area, chlorophyll content and sugar that result in better crop yield (Arora et al.2012; Gopinath et al. 2014). Almeelbi and bezbaruah (2014) reported the effect of iron- NPs on Fe content in spinach roots, stem and leaves increased 11-21 times in hydroponic solution. Also, Zn NPs significantly enhanced shoot $(10.8 \%)$, chlorophyll content $(18.4 \%)$ and grain yield $(29.5 \%)$ in pearl millet (Tarafdar et al. 2014). Mixture nanoparticles of $\mathrm{TiO}_{2}$ and $\mathrm{SiO}_{2}$ increased the nitrate reductase activity and stimulated the antioxidant system in soybean ( $\mathrm{Lu}$ et al. 2002). Therefore, root elongation in soybean was promoted at a particular concentration of $\mathrm{ZnO}$ NPs (Lopez-Moreno et al. 2010). Plant growth and development enhanced by nanoSiO, by increasing photosynthetic rate, transpiration rate, electron transport rate (Xie et al. 2011; Al-
Whaibi 2014). According to Gupta and Tripathi (2011), $\mathrm{TiO}_{2}$ NPs may be used for production of $\mathrm{H}_{2}$ as a fuel by decomposition of organic compounds. Foliar application of $\mathrm{ZnO} \mathrm{NP}$ at $1.5 \mathrm{mg} \mathrm{\textrm {L } ^ { - 1 }}$ concentration improved biomass as compared to foliar application of $\mathrm{ZnSO}_{4}$ in chickpea (Burman et al. 2013). The mode of action of these nanoparticles by which they take part in the growth and development of plants needed to study. Also, plant species and environmental factors will affect the uptake and accumulation of NPs is still to be investigated.

\section{Nanoparticles application in agro-wastes management}

Enormous amounts of wastes generated from different agricultural sectors, where some of these agri-wastes may be offensive odor as well as their decayed matters could alter the $\mathrm{pH}$ of soil and the disposal of agricultural wastes have become a major problem (Bello et al. 2016). The agricultural wastes or agro-wastes can be defined as the crop fraction, which does not constitute the harvested crop itself (Kallel et al. 2016; García et al. 2016). These agro-wastes depend mainly in their composition on the crop source, conditions of growing and harvesting crop (García et al. 2014). Every year are generated about 140 billion tons of industrial and agricultural wastes driving by processing of animal and plant's raw materials (FAO 2011). Industrial and agricultural wastes include solid wastes, air pollutants and wastewaters. They can be reduced and/ or treated by process control, emission control and waste treatment. Therefore, the application of nanoparticles could help in improving the environment and controlling the pollution (Ghasemi et al. 2017).

Among the solutions is the nanotechnology approach to help in the smooth transition to alternative and renewable energy sources (Bello et al. 2016; Mekki et al. 2016; García et al. 2016; Adebisi et al. 2017) through using the nanotechnology in transesterification, pyrolysis, gasification, hydrogenation and the reforming of biomass (Fryxell and Cao 2007; Galadima and Muraza 2015). Furthermore, the application of microorganisms or enzymes (biocatalysts) has gained increasing attention as a possible means to decrease the environmental industrial wastes as well as to convert these wastes to potentially valuable products such as bioplastics and biopolymers (Amulya et al. 2016; Emadian et al. 2017). Also, in the second-generation conversion, 
liquid biofuels depends on biomass cellulosics, which convert to ethanol and biodiesel (Trindade 2011; Valenstein 2012; Zhang et al. 2016). Solid wastes (spent tea) could be used for the production of biodiesel, bioethanol and also hydrocarbon fuel gases through (i) gasification (yielded $60 \%$ liquid extract, $28 \%$ fuel gases and $12 \%$ charcoal as well as gaseous products contain 53.03\% ethene, $37.18 \%$ methanol, and $4.59 \%$ methane). (ii) transesterification gave $40.79 \%$ ethyl ester (biodiesel), and (iii) production of bioethanol $57.49 \%$ by Aspergillus niger (Mahmood and Hussain 2010).

The management of agro-wastes using nanoparticles is a crucial issue worldwide. This issue has at least two dimensions; the first includes the conversion of the agro-wastes into energy (Nanda et al. 2016; Adebisi et al. 2017) and the second represents using these agrowastes in removing different types of pollutants from water (Bello et al. 2014; Bello et al. 2016). Moreover, the agro-wastes could be handled as materials for biomass production or a renewable source as well as recyclable or biodegradable products. Hence, it is proposed that the agriwaste materials are economic and eco-friendly (Kumar and Kumar 2014). On the other hand, several agro-wastes have been used in removing of different pollutants from aqueous solutions such as cassava peel (Horsfall et al. 2006), orange peel (Ningchuan et al. 2009), rice bran (Suzuki et al. 2007), periwinkle shell (Bello et al. 2008), coconut shell (Bello and Ahmad 2012), coconut husk (Tan et al. 2008), cocoa pod husk (Bello and Ahmad 2011), mango leaf (Khan et al. 2011), loquat leaves (Akl and Salem 2012), aluminacoated carbon nanotubes (Gupta et al. 2011), multi-walled carbon nanotubes-ionic liquidcarbon paste electrode (Khani et al. 2010) as reported by Bello et al. (2016).

Risk and safety of nanomaterials in agroproduction

Due to the rapid propagation in nanotechnology, huge amounts of nanomaterials have been applied in all our life sectors (Rico et al. 2011) including food additives and packing (Peters et al. 2016), soil and water remediation (Gil-Díaz et al. 2017), cosmetics (Nazarenko et al. 2012), textiles (Geranio et al. 2009), electronics (Shulaker et al. 2013), medicine (Murday et al. 2009), etc (Hu et al. 2016; Priester et al. 2017). So, these nanomaterials could be released into the soils, waters, air, and interact with the biological tissues because of their small size as well as the high surface activity (Holden et al. 2013). Therefore, there is an urgent need to follow different biological responses related to both human health and the ecological safety (Oomen et al. 2014; Syberg and Hansen 2016; Boonrungsiman et al. 2017). Different investigations regarding the adverse effects of nanomaterials have been carried out including the biological, medical and terrestrial environments (Hu et al. 2016; Kwak and An 2016; Mattsson and Simkó 2016).

There are risks of adverse and unintended consequences with nanotechnology and it is important to pay attention to public views regarding new technologies in agro-production during the product development stages (ZuverzaMena et al. 2017). This risk is due to the small size and large surface area of nanoparticles, which allow easy dispersion, might cross anatomical barriers and showing potential toxicity (Rico et al. 2011). In the agro-production sector, millions of small farmers can be a leading health risk by using of nanofertilizers and nanopesticides which allow easy dispersal into the soil, water and atmosphere (Tripathi et al. 2017). Nanoparticles could enter the food chain via nutrient/pesticide systems or through processed foods raising concerns of toxicity in the ecosystem (Mattsson and Simkó 2016). Therefore, life cycle analysis, particle uptake by plants, bio-distribution and entry into the food chain, etc need a thorough investigation before these tools are used as products in agroproduction sector (Rico et al. 2011; Holden et al. 2014, 2016).

It could be concluded that, for the regulatory purposes as well as the risk management activities, it should be assessed the risk assessment of manufactured nanomaterials (Mattsson and Simkó 2016). This assessment of nanomaterial risks requires knowing some information about the exposure time, the potential hazard and the dose as well as the kind of nanomaterials. Moreover, the life cycle of nanomaterials, the possible changing in nanomaterials and its properties over time (Bicho et al. 2016; Priester et al. 2017). There are still open questions concerning the fate and behavior of nanomaterials in different environments, despite of an accepted progress in developing the risk assessment of nanomaterials (Schulte et al. 2016; Mattsson and Simkó 2016). According to the European Parliament, there are some regulations regarding agro-production as follows (Lee and Stokes 2016): 
1. Legislation on food additives (Regulation: EC no. $1333 / 2008$, Art 12),

2. Legislation on food information for consumers (Regulation: EU no. $1169 / 2011$, e.g. Art 18),

3. Legislation on cosmetic products (Regulation: EC no. $1223 / 2009$, e.g. Art 13 (1),

4. Legislation on waste electrical and electronic equipment (Directive 2012/19/EU, Art 8 (4),

5. Legislation on restrictions on hazardous substances in electrical and electronic equipment (Directive 2011 /65/EU, Recital 16),

6. Legislation on biocidal products (Regulation: EU no. 528/2012, e.g. Art 19 (1),

7. Legislation on food for infants (Regulation: EU no. 609/2013, Art 9 (2)

Therefore in the near future, it will be possible to perform a complete and scientifically sound risk assessment of application of engineered nanoparticles in all industrial and public sectors, including agriculture, healthcare, transport, energy, materials, information and communication technologies.

\section{Conclusion}

There is no doubt that, the global natural resources including water and lands are very limited. So, an urgent need is essential to increase use efficiency of these resources as well as minimize the agro-ecology damage through using the effective modern technologies like nanotechnology. Concerning nanotechnology, many nanomaterials have been penetrated several fields including (1) enhancement of the agricultural productivity, (2) production, conversion and storage energy, (3) water treatment and its remediation, (4) remediation of air pollution, (5) diagnosis and screening of diseases, (6) delivery systems of fertilizers and drugs, (7) processing, coating, packaging and storage of foods, (8) durability of construction, (9) monitoring of health and (10) detection, control of vector and pests. On the other hand, serious and terrible threats face the world including the global security resulting from the continuous global changes. This global security includes security of water, soil, food, energy, environment, communication, information, etc. Therefore, sustainable agro-production mainly depends on many previous securities including soil, water, energy and food security. Furthermore, there is closed links among these securities such as food, water, soil and energy security, where the agro-food production and its security based on the integration among all these securities. It is worth mentioning that, nanotechnology applications can be used to achieve through these previous securities. Concerning the applications of nanotechnology in agriculture sector, it could be noticed that nanotechnology may be totally revolutionized this sector through its ability to penetrate different agro-fields including (1) treatment and detection of plant diseases, (2) nanobiosensors, (3) nanofertilizers, (4) nanopesticides and (5) gene transfer as smart delivery systems. Whereas, the over-application of nanomaterials in agriculture leads to the negative effects representing the toxic action of these nanomaterials in the agroecosystems.

It is worth to mention that, nearly all agricultural practices may be touched or penetrated through the nanotechnology. So, several agro-products could not be only fabricated using nanomaterials but also a huge amount of agro-wastes could be managed using these nanomaterials. Hence, great challenges have been created seeking for the sustainability of agro-production including (1) global soil security, (2) water security, (3) energy security, (4) food security, (5) reduction of poverty and (6) improvement of human public health. Therefore, many risks have been resulted from this using in agro-production and hence safety approaches should be regulated. Although these nanoparticles may have the ability in conservation of both water and lands through certain applied concentrations, they substantially should also sustain or conserve the environment. Therefore, further investigations are needed in our handling nanoparticle applications for the sustainable agroproduction, the management of agro-wastes, the risks and safety of these nanoparticles in different agroecosystem compartments.

\section{Acknowledgments}

Authors thank the outstanding contribution of EFOP-3.6.2-16-2017-00001 Research of complex rural economic and sustainable development, elaboration of its service networks in the Carpathian basin. The research was financed by the Higher Education Institutional Excellence Program of the Ministry of Human Capacities in Hungary, within the framework of the biotechnology thematic program of the University 
of Debrecen 20428-3/2018/FEKUTSTRAT.

\section{References}

Abdel-Haliem M. E.F., H. S. Hegazy, N. S. Hassan, D. M. Naguib (2017). Effect of silica ions and nano silica on rice plants under salinity stress. Ecological Engineering, 99: 282-289.

Abhilash P. C., V. Tripathi, S. A. Edrisi, R. K. Dubey, M. Bakshi, P. K. Dubey, H. B. Singh and S. D. Ebbs (2016). Sustainability of crop production from polluted lands. Energ. Ecol. Environ. 1(1): 54-65. DOI: 10.1007/s40974-016-0007-x.

Adebisi J. A., J.O. Agunsoye, S. A. Bello, I.I. Ahmed, O. A. Ojo, S. B. Hassan (2017). Potential of producing solar grade silicon nanoparticles from selected agro-wastes: A review. Solar Energy, 142: 68-86.

Akl M. A., Salem N. M. (2012). Biosorption of copper(II) and lead(II) ions from aqueous solutions by modified loquat (Eriobotrya japonica) leaves (MLL). J Chem. Eng. Mater. Sci., 3(1): 7-17.

Alexiou N., S. Basagiannis, S. Petridou (2016). Formal security analysis of near field communication using model checking. Computers \& Security, 60: 1-14.

Al-Garawi Z. S., G. E. Kostakis and L. C. Serpell (2016). Chemically and thermally stable silica nanowires with a $\beta$-sheet peptide core for bionanotechnology. J Nanobiotechnol 14:79. DOI: 10.1186/s12951016-0231-8

Almeelbi T., Bezbaruah A. (2014). Nanoparticle-sorbed phosphate: iron and phosphate bioavailability studies with Spinacia oleracea and Selenastrum capricornutum, Acs Sustain Chem Eng. 2(7): 16251632.

Al-Samarrai A.M. (2012). Nanoparticles as alternative to pesticides in management plant diseases a review. International Journal of Scientific and Research Publications; 2 (4):1-4.

Alvarez A., J. M. Saez, J. S. D. Costa, V. L .Colin, M. S. Fuentes, S. A. Cuozzo, C. S. Benimeli, M. A. Polti, M. J. Amoroso (2017). Actinobacteria: Current research and perspectives for bioremediation of pesticides and heavy metals. Chemosphere, 166: 41-62

Álvarez S. P., N. E. L. López, J. M. Lozano, E. A. R. Negrete and M. E. S. Cervantes (2016). Plant Fungal Disease Management Using Nanobiotechnology as a Tool. In: R. Prasad (ed.), Advances and Applications through Fungal Nanobiotechnology, Fungal Biology, pp: 169 - 192. DOI: 10.1007/978-
3-319-42990-8 8, Springer International Publishing Switzerland

Al-Whaibi M.H. (2014). Role of nano-SiO2 in germination of tomato (Lycopersicum esculentum seeds Mill.) Saudi Biol Sci, 2113-17.

Amulya K., M. V. Reddy, M. V. Rohit, S. V. Mohan (2016). Wastewater as renewable feedstock for bioplastics production: understanding the role of reactor microenvironment and system $\mathrm{pH}$. Journal of Cleaner Production, 112 (Part 5): 4618-4627.

An Y. and Q. Dong (2015). Nano-enhanced Biological Treatment of Agricultural Wastewater. In: M. Rai et al. (eds.), Nanotechnologies in Food and Agriculture, pp: 267 - 297. DOI: 10.1007/978-3319-14024-7 12, Springer International Publishing Switzerland

Anandharamakrishnan C. (2014). Characterization of Nanoparticles. In: C. Anandharamakrishnan, Techniques for Nanoencapsulation of Food Ingredients, DOI: 10.1007/978-1-4614-9387-7_8, pp: $65-67$. Springer Briefs in Food, Health, and Nutrition

Anjum N. A., S. S. Gill, A. C. Duarte, E. Pereira, I. Ahmad (2013). Silver nanoparticles in soil-plant systems. J Nanopart Res 15: 1896. DOI: 10.1007/ s11051-013-1896-7

Ansari M.I.H., S. Hassan, A. Qurashi, F.A. Khanday (2016). Microfluidic-integrated DNA nanobiosensors. Biosensors and Bioelectronics, 85: $247-260$

Antisari L. V., S. Carbone, A. Gatti, S. Ferrando, Mi Nacucchi, F. De Pascalis, C. Gambardella, L. Badalucco, V. A. Laudicina (2016). Effect of cobalt and silver nanoparticles and ions on Lumbricus rubellus health and on microbial community of earthworm faeces and soil. Applied Soil Ecology, 108: $62-71$

Antunes F. A. F., S. Gaikwad, A. P. Ingle, R. Pandit, J. C. dos Santos, M. Rai and S. S. da Silva (2017). Bioenergy and Biofuels: Nanotechnological Solutions for Sustainable Production. In: M. Rai, S.S. da Silva (eds.), Nanotechnology for Bioenergy and Biofuel Production, Green Chemistry and Sustainable Technology, pp: 3 18. DOI: 10.1007/978-3-319-45459-7_1, Springer International Publishing AG

Aouada F. A. and M. R. de Moura (2015). Nanotechnology Applied in Agriculture: Controlled Release of Agrochemicals. In: M. Rai et al. (eds.), 
Nanotechnologies in Food and Agriculture, pp: 103 - 118. DOI 10.1007/978-3-319-14024-7 5, Springer International Publishing Switzerland

Arodudu O., K. Helming, H. Wiggering, A. Voinov (2017). Towards a more holistic sustainability assessment framework for agro-bioenergy systems - A review. Environmental Impact Assessment Review, 62: 61-75

Arora S., Sharma P., Kumar S., Nayan R., Khanna P.K., Zaidi M.G.H. (2012). Gold-nanoparticle induced enhancement in growth and seed yield of Brassica juncea, Plant Growth Regul, 66: 303-310.

Ashoka P., R. S. Meena, N. Gogoi, S. Kumar, G. S. Yadav, J. Layek (2017). Green Nanotechnology is a Key for Eco-friendly Agriculture. Journal of Cleaner Production, 142 (Part 4): 4440-4441.

Bäcker M., C. Koch, S. Eiben, F. Geiger, F. Eber, H. Gliemann, A. Poghossian, C. Wege, M. J. Schöning (2017). Tobacco mosaic virus as enzyme nanocarrier for electrochemical biosensors. Sensors and Actuators B: Chemical, 238: 716-722

Baker N. J., B .A. Bancroft, T. S. Garcia (2013). A metaanalysis of the effects of pesticides and fertilizers on survival and growth of amphibians. Science of The Total Environment, 449: 150-156.

Balaji A.P.B., A. Ashu, S. Manigandan, T. P. Sastry, A. Mukherjee, N. Chandrasekaran (2017). Polymeric Nanoencapsulation of insect repellent: Evaluation of its bioefficacy on Culex quinquefasciatus mosquito population and effective impregnation onto cotton fabrics for insect repellent clothing. Journal of King Saud University - Science, http:// dx.doi.org/10.1016/j.jksus.2016.12.005

Balaji A.P.B., T.P. Sastry, S. Manigandan, A. Mukherjee, N. Chandrasekaran (2017). Environmental benignity of a pesticide in soft colloidal hydrodispersive nanometric form with improved toxic precision towards the target organisms than non-target organisms. Science of The Total Environment, 579: 190-201

Balaure P.C., D. Gudovan, I. Gudovan (2017). Nanopesticides: a new paradigm in crop protection. In: A. M. GRUMEZESCU (Ed.), New Pesticides and Soil Sensors. Nanotechnology in the AgriFood Industry, Volume 10, Academic Press, 129192. http://dx.doi.org/10.1016/B978-0-12-804299$1.00005-9$

Balapour M., A. Ramezanianpour, E. Hajibandeh (2017). An investigation on mechanical and durability properties of mortars containing nano and micro RHA. Construction and Building Materials, 132: $470-477$

Bapat G., C. Labade, A. Chaudhari, S. Zinjarde (2016). Silica nanoparticle based techniques for extraction, detection, and degradation of pesticides. Advances in Colloid and Interface Science, 237: 1-14

Bäuerlein P. S., E. Emke, P. Tromp, J. A.M.H. Hofman, A. Carboni, F. Schooneman, P. de Voogt, A. P. van Wezel (2017). Is there evidence for man-made nanoparticles in the Dutch environment? Science of The Total Environment, 576: 273-283

Baun A., Hartmann N.B., Grieger K., Kusk K.O. (2008). Ecotoxicity of engineered nanoparticles to aquatic invertebrates: a brief review and recommendations for future toxicity testing. Ecotoxicol, 17: 387-395.

Baun A., Sørensen S.N., Rasmussen R.F., Hartmann N.B., Koch C.B. (2008). Toxicity and bioaccumulation of xenobiotic organic compounds in the presence of aqueous suspensions of aggregates of nano-C60. Aquat Toxicol, 86: 379387.

Bazin I., S. A. Tria, A. Hayat, J-L. Marty (2017). New biorecognition molecules in biosensors for the detection of toxins. Biosensors and Bioelectronics, 87: 285-298.

Bello O. S., E. Seun Owojuyigbe, M. A. Babatunde, F. E. Folaranmi (2016). Sustainable conversion of agro-wastes into useful adsorbents. Appl Water Sci, DOI: $10.1007 / \mathrm{s} 13201-016-0494-0$

Bello O.S., Adegoke K.A., Bello O.U., Lateef I.O. (2014). Sequestering Nikel (II) Ions from aqueous solution using various adsorbents: a review. Pak J Anal Environ 15(1):1-17

Bello O.S., Adeogun A.I., Ajaelu J.C., Fehintola E.O. (2008). Adsorption of methylene blue onto activated carbon derived from periwinkle shells: kinetics and equilibrium studies. Chem Ecol 24(4): 285-295.

Bello O.S., Ahmad M.A. (2011). Adsorptive removal of a synthetic textile dye using coca pod husks. Toxicol Environ Chem 93(7): 1298-1308

Bello O.S., Ahmad M.A. (2012). Coconut (Cocos nucifera) shell based activated carbon for the removal of malachite green dye from aqueous solutions. Sep Sci Technol 47(6): 903-912.

Berhanu D., Dybowska A., Misra S.K., Stanley C.J., Ruenraroengsak P., Boccaccini A.R., et al. (2009). 
Characterisation of carbon nanotubes in the context of toxicity studies. Environmental Health, 8 (Suppl. 1), $\mathrm{S} 3$.

Bhat S. S., A. Qurashi, F. A. Khanday (2017). ZnO nanostructures based biosensors for cancer and infectious disease applications: Perspectives, prospects and promises. TrAC Trends in Analytical Chemistry, 86: 1-13.

Bhattacharyya A., P. Duraisamy, M. Govindarajan, A. A. Buhroo and R. Prasad (2016). Nano-Biofungicides: Emerging Trend in Insect Pest Control. In: R. Prasad (ed.), Advances and Applications through Fungal Nanobiotechnology, Fungal Biology, pp: 307 - 319. DOI: 10.1007/978-3-319-42990-8_15, Springer International Publishing Switzerland

Bhau B. S., P. Phukon, R. Ahmed, B. Gogoi, B. Borah, J. Baruah, D. K. Sharma, and S. B. Wann (2016). A Novel Tool of Nanotechnology: Nanoparticle Mediated Control of Nematode Infection in Plants. In: D. P. Singh et al. (eds.), Microbial Inoculants in Sustainable Agricultural Productivity, DOI: 10.1007/978-81-322-2644-4_16, Springer India

Bicho R. C., T. Ribeiro, N. P. Rodrigues, J. J. ScottFordsmand, M. J.B. Amorim (2016). Effects of Ag nanomaterials $(\mathrm{NM} 300 \mathrm{~K})$ and $\mathrm{Ag}$ salt $\left(\mathrm{AgNO}_{3}\right)$ can be discriminated in a full life cycle long term test with Enchytraeus crypticus. Journal of Hazardous Materials, 318: 608-614.

Biswal S.K., Nayak A.K., Parida U.K., Nayak P.L. (2012). Applications of nanotechnology in agriculture and food sciences. IJSID; 2(1): 21-36.

Boonrungsiman S., W. Suchaoin, P. Chetprayoon, N. Viriya-empikul, S.Aueviriyavit, R. Maniratanachote (2017). Shape and surface properties of titanate nanomaterials influence differential cellular uptake behavior and biological responses in THP-1 cells. Biochemistry and Biophysics Reports, 9: 203-210.

Boruah P. K., B. Sharma, N. Hussain and M. R. Das (2017). Magnetically recoverable $\mathrm{Fe}_{3} \mathrm{O}_{4}$ /graphene nanocomposite towards efficient removal of triazine pesticides from aqueous solution: Investigation of the adsorption phenomenon and specific ion effect. Chemosphere, 168: 1058-1067.

Bouldin J.L., Ingle T.M., Sengupta A., Alexander R, Hannigan R.E., Buchanan R.A. (2008). Aqueous toxicity and food chain transfer of quantum dots in freshwater algae and Ceriodaphnia dubia. Environ Toxicol Chem, 27: 1958-1963.

Bouma J, M.K. van Ittersum, J.J. Stoorvogel, N.H.
Batjes, P. Droogers and M. M. Pulleman (2017). Soil Capability: Exploring the Functional Potentials of Soils. In: D.J. Field et al. (eds.), Global Soil Security, Progress in Soil Science, pp: $27-44$. DOI: 10.1007/978-3-319-43394-3_3, Springer International Publishing Switzerland

Bouma J., McBratney A. (2013). Framing soils as an actor when dealing with wicked environmental problems. Geoderma 200-201: 130-139

Bradfield S J., P Kumar, J C. White, S D. Ebbs (2017). Zinc, copper, or cerium accumulation from metal oxide nanoparticles or ions in sweet potato: Yield effects and projected dietary intake from consumption. Plant Physiology and Biochemistry, 110: $128-137$.

Brandelli A., L. F. W. Brum and J. H. Z. dos Santos (2016). Nanobiotechnology Methods to Incorporate Bioactive Compounds in Food Packaging. In: S. Ranjan et al. (eds.), Nanoscience in Food and Agriculture 2, Sustainable Agriculture Reviews 21, DOI: 10.1007/978-3-319-39306-3_2, Springer International Publishing Switzerland

Brock D.A., Douglas T.E., Queller D.C., Strassmann J.E. (2011). Primitive agriculture in a social amoeba. Nature; 469 (7330): 393-396.

Burman U., Saini M.P.K. (2013). Effect of zinc oxide nanoparticles on growth and antioxidant system of chickpea seedlings, Toxicol Environ Chem, 95(4): 605-612.

Calanca P. P. (2017). Effects of Abiotic Stress in Crop Production. In: M. Ahmed, C.O. Stockle (eds.), Quantification of Climate Variability, Adaptation and Mitigation for Agricultural Sustainability, pp: 165 - 180. DOI: 10.1007/978-3-319-32059-5 8 Springer International Publishing Switzerland

Campos E. V. R., J. L.de Oliveira, L. F. Fraceto and B. Singh (2015). Polysaccharides as safer release systems for agrochemicals. Agron. Sustain. Dev. 35: 47-66. DOI: 10.1007/s13593-014-0263-0

Carbone M, D T Donia, G Sabbatella, R Antiochia (2016). Silver nanoparticles in polymeric matrices for fresh food packaging. Journal of King Saud University - Science, 28 (4): 273-279

Carré F., J Caudeville, R Bonnard, V Bert, P Boucard and M Ramel (2017). Soil Contamination and Human Health: A Major Challenge for Global Soil Security. In: D.J. Field et al. (eds.), Global Soil Security, Progress in Soil Science, pp: $275-$ 295. DOI 10.1007/978-3-319-43394-3_2, Springer 
International Publishing Switzerland

Cecchin I, K R. Reddy, A Thomé, E F Tessaro, F Schnaid (2016). Nanobioremediation: Integration of nanoparticles and bioremediation for sustainable remediation of chlorinated organic contaminants in soils. International Biodeterioration \& Biodegradation http://dx.doi.org/10.1016/j. ibiod.2016.09.027

Chalco-Sandoval W, M J Fabra, A López-Rubio, J M. Lagaron (2017). Use of phase change materials to develop electrospun coatings of interest in food packaging applications. Journal of Food Engineering, 192: 122-128

Chen H, Yada R (2011). Nanotechnologies in agriculture: new tools for sustainable development. Trends Food Sci Technol 22: 585-594.

Chen W-Y, T Suzuki and M Lackner (2017). Handbook of Climate Change Mitigation and Adaptation. DOI: $\quad$ 10.1007/978-3-319-14409-2, Springer International Publishing

Chhipa H, Joshi P (2016). Nanofertilisers, nanopesticides and nanosensors in agriculture. In: Ranjan S, Dasgupta N, Lichtfouse E (eds.) Nanoscience in Food and Agriculture 1, Sustainable Agriculture Reviews, vol. 20. Springer, pp 247-282. doi:10.1007/ 978-3-319-39303-2

Chhipa H. (2016). Nanofertilizers and nanopesticides for agriculture. Environ Chem Lett, DOI: 10.1007/ s10311-016-0600-4

Chowdhury P, M Gogoi, S Das, A Zaman, P Hazarika, $S$ Borchetia and T Bandyopadhyay (2016). Intellectual Property Rights for Nanotechnology in Agriculture. In: S. Ranjan et al. (eds.), Nanoscience in Food and Agriculture 2, Sustainable Agriculture Reviews 21, DOI 10.1007/978-3-319-39306-3_1, Springer International Publishing Switzerland

Chunjaturas W, J A. Ferguson, W Rattanapichai, M J. Sadowsky, K Sajjaphan (2014). Shift of bacterial community structure in two Thai soil series affected by silver nanoparticles using ARISA. World J Microbiol Biotechnol 30: 2119-2124. DOI: 10.1007/s11274-014-1633-0

Cifuentes Z, Custardoy L, de la Fuente JM, Marquina C, Ibarra MR, Rubiales D, Pérez-de-Luque A (2010). Absorption and translocation to the aerial part of magnetic carbon-coated nanoparticles through the root of different crop plants. J Nanobiotechnology, 8: 26.

Conley DJ, Paerl HW, Howarth RW, Boesch DF,
Seitzinger SP, et al. (2009). Ecology controlling eutrophication: nitrogen and phosphorus, Science, 323: 1014-1015.

Corradini E., De Moura M., Mattoso L. (2010). preliminary study of the incorporation of NPK fertilizer Into chitosan nanoparticles, Express Polym Lett. 4: 509-515.

Da Costa M.V.J. and P. K. Sharma (2016). Effect of copper oxide nanoparticles on growth, morphology, photosynthesis, and antioxidant response in Oryza sativa. Photosynthetica 54 (1): 110-119. DOI: 10.1007/s11099-015-0167-5

Das A., R Ray, N Mandal and K Chakrabarti (2016). An analysis of transcripts and enzyme profiles in drought stressed jute (Corchorus capsularis) and rice (Oryza sativa) seedlings treated with $\mathrm{CaCl}_{2}$, hydroxyapatite nano-particle and $\beta$-amino butyric acid. Plant Growth Regul 79: 401-412. DOI: 10.1007/s10725-015-0144-9

Dasgupta N, S Ranjan, D Mundekkad, C Ramalingam, R Shanker, A Kumar (2015). Nanotechnology in agro-food: From field to plate. Food Research International, 69: 381-400

Dasgupta N., S Ranjan, A R Chakraborty, C Ramalingam, R Shanker and A Kumar (2016). Nanoagriculture and Water Quality Management. In: S. Ranjan et al. (eds.), Nanoscience in Food and Agriculture 1, Sustainable Agriculture Reviews 20, pp: 1 - 42. DOI: 10.1007/978-3-319-39303-2_1, Springer International Publishing Switzerland

Davarpanah S., A Tehranifar, G Davarynejad, J Abadía, R Khorasani (2016). Effects of foliar applications of zinc and boron nano-fertilizers on pomegranate (Punica granatum cv. Ardestani) fruit yield and quality. Scientia Horticulturae, 210: 57-64

De A, R Bose, A Kumar and S Mozumdar (2014). Management of Insect Pests Using Nanotechnology: As Modern Approaches. In: De et al. (eds.) Targeted Delivery of Pesticides Using Biodegradable Polymeric Nanoparticles, pp: $29-$ 33. DOI: 10.1007/978-81-322-1689-6_8, Springer Briefs in Molecular Science

De La Cueva Bueno P, L Gillerman, R Gehr, G Oron (2017). Nanotechnology for sustainable wastewater treatment and use for agricultural production: A comparative long-term study. Water Research, 110: 66-73.

De la Rosa G, Lopez-Moreno ML, De Haro D, Botez CE; Peralta-Videa, JR, Gardea-Torresdey J (2013).

Env. Biodiv. Soil Security Vol. 3 (2019) 
Effects of $\mathrm{ZnO}$ nanoparticles in alfalfa, tomato, and cucumber at the germination stage: root development and X-ray absorption spectroscopy studies. Pure Appl. Chem. 85(12): 2161-2174.

de Lourdes Oshiro M, E Oshiro, T E M da Silva, W Waissmann and W Engelmann (2017). Nanotechnologies and the Risk Management of Biofuel Production. In: M. Rai, S.S. da Silva (eds.), Nanotechnology for Bioenergy and Biofuel Production, Green Chemistry and Sustainable Technology, pp: 343 - 364. DOI: 10.1007/978-3319-45459-7_15, Springer International Publishing AG 2017

de Oliveira J A R, L H S Martins, A Komesu and J M Neto (2017). Nanotechnology Applications on Lignocellulosic Biomass Pretreatment. In: M. Rai, S.S. da Silva (eds.), Nanotechnology for Bioenergy and Biofuel Production, Green Chemistry and Sustainable Technology, pp: 19 37. DOI: 10.1007/978-3-319-45459-7_2, Springer International Publishing AG

De Rosa MC, Monreal C, Schnitzer M, Walsh R, Sultan Y (2010). Nanotechnology in fertilizers. Nat Nanotechnol 5: 91-94.

De S and R Luque (2016). Nanomaterials for the Production of Biofuels. In: Q. Li (ed.), Nanomaterials for Sustainable Energy, Nano Science and Technology, pp: 559 - 582. DOI 10.1007/978-3-319-32023-6_15, Springer International Publishing Switzerland

DEFRA, Department of Environment, Food and Rural Affairs, UK (2007). Characterizing the potential risk posed by engineered nanoparticles. DEFRA no. 91 [http://www.defra.gov.uk/publications/files/ pb12901-nanoparticlesriskreport- 071218.pdf]].

Dhawan A, Sharma V (2010). Toxicity assessment of nanomaterials: Methods and challenges. Analytical and Bioanalytical Chemistry, 398: 589-605.

Ditta A., M. Arshad and M. Ibrahim (2015). Nanoparticles in Sustainable Agricultural Crop Production: Applications and Perspectives. In: M.H. Siddiqui et al. (eds.), Nanotechnology and Plant Sciences, pp: 55 - 75. DOI: 10.1007/978-3319-14502-0_4, Springer International Publishing Switzerland

Doolette C. L., M J. McLaughlin, J K. Kirby, D A. Navarro (2015). Bioavailability of silver and silver sulfide nanoparticles to lettuce (Lactuca sativa): Effect of agricultural amendments on plant uptake. Journal of Hazardous Materials, 300: 788-795
Dressler F. and F Kargl (2012). Towards security in nano-communication: Challenges and opportunities. Nano Communication Networks, 3 (3): $151-160$

Dubey A. and D. R. Mailapalli (2016). Nanofertilisers, Nanopesticides, Nanosensors of Pest and Nanotoxicity in Agriculture. In: E. Lichtfouse (ed.), Sustainable Agriculture Reviews, Sustainable Agriculture Reviews 19, pp: 307 - 330. DOI: 10.1007/978-3-319-26777-7_7, Springer International Publishing Switzerland

Duran N, Marcato PD, De S, Gabriel IH, Alves OL, Esposito E (2007). Antibacterial effect of silver nanoparticles produced by fungal process on textile fabrics and their effluent treatment. $J$ Biomed Nanotechnol. 3: 203-208.

Dwivedi S, Q Saquib, AA. Al-Khedhairy and J Musarrat (2016). Understanding the Role of Nanomaterials in Agriculture. In: D.P. Singh et al. (eds.), Microbial Inoculants in Sustainable Agricultural Productivity, pp: 271 - 288. DOI: 10.1007/978-81-322-26444_17, Springer India

EC, European Commission (2017). http://ec.europa.eu/ growth/industry/key-enablingtechnologies/index en.htm. Extracted by 12 January 2017.

El-Ramady H., N. Abdalla, H. S. Taha, T. Alshaal, A. El-Henawy, M. Elmahrouk, Y. Bayoumi, T. Shalaby, A. H. Al-Saeedi, M. Amer, S. Shehata, M. Fári, É. Domokos-Szabolcsy, A. Sztrik, J. Prokisch, E. A. H. Pilon-Smits, M. Pilon, D. Selmar, S. Haneklaus and E. Schnug (2017b). Plant nanonutrition: perspectives and challenges. In: S. Ranjan et al. (eds.), Nanoscience in Food and Agriculture 4, Sustainable Agriculture Reviews 24, Springer International Publishing Switzerland (in press)

El-Ramady H., T Alshaal, M Abowaly, N Abdalla, H S. Taha, A. H. Al-Saeedi, T. Shalaby, M. Amer, M. Fári, É. Domokos-Szabolcsy, A. Sztrik, J. Prokisch, D. Selmar, E. A. H. Pilon-Smits and M. Pilon (2017a). Nanoremediation: towards sustainable crop production. In: S. Ranjan et al. (eds.), Nanoscience in Food and Agriculture 4, Sustainable Agriculture Reviews 24, Springer International Publishing Switzerland (in press)

El-Temsah Y. S., A Sevcu, K Bobcikova, M Cernik, E J. Joner (2016). DDT degradation efficiency and ecotoxicological effects of two types of nanosized zero-valent iron (nZVI) in water and soil. Chemosphere, 144: 2221-2228

Emadian S. M., T. T. Onay, B Demirel (2017).

Env. Biodiv. Soil Security Vol. 3 (2019) 
Biodegradation of bioplastics in natural environments. Waste Management, 59: 526-536

Esteban-Tejeda L, Malpartida F, Esteban-Cubillo A, Pecharromán C, Moya JS (2009). Antibacterial and antifungal activity of a soda-lime glass containing copper nanoparticles. Nanotechnology 20(50): 505701 .

Fallah S. and M. Nematzadeh (2017). Mechanical properties and durability of high-strength concrete containing macro-polymeric and polypropylene fibers with nano-silica and silica fume. Construction and Building Materials, 132: 170-187

FAO (2011). Fisheries and Aquaculture Department, editors. The State of World Fisheries and Aquaculture 2010. Rome, Italy.

Farrell D, Hoover M, Chen H, Friedersdorf L (2013). Overview of Resources and Support for Nanotechnology for Sensors and Sensors for Nanotechnology: Improving and Protecting Health, Safety, and the Environment. Arlington VA: US National Nanotechnology Initiative; Available from: http://nano.gov/sites/default/files/pub resource/nsi_nanosensors_resources_for_web.pdf. Accessed April 19, 2014

Fernandes J. P., C. M R. Almeida, F Andreotti, L Barros, T Almeida, A P. Mucha (2017). Response of microbial communities colonizing salt marsh plants rhizosphere to copper oxide nanoparticles contamination and its implications for phytoremediation processes. Science of The Total Environment (In Press) http://dx.doi.org/10.1016/j. scitotenv.2017.01.015

Field D J., C L. S. Morgan and A B. McBratney (2017). Global Soil Security. Progress in Soil Science Series, Springer International Publishing Switzerland, DOI: 10.1007/978-3-319-43394-3

Field D. J. (2017). Soil Security: Dimensions. In: D.J. Field et al. (eds.), Global Soil Security, Progress in Soil Science, pp: 4 - 23. DOI: 10.1007/978-3319-43394-3_2, Springer International Publishing Switzerland

Floris B, P Galloni, F Sabuzi and V Conte (2017). Metal systems as tools for soil remediation. Inorganica Chimica Acta, 455 (Part 2): 429-445

Formentini T A, S Legros, C V S Fernandes, A Pinheiro, M Le Bars, C Levard, F J K Mallmann, M da Veiga, E Doelsch (2017). Radical change of Zn speciation in pig slurry amended soil: Key role of nano-sized sulfide particles. Environmental Pollution, (In
Press)

Frewer LJ, Norde W, Fischer ARH, Kampers FWH (2011). Nanotechnology in the Agri-Food Sector: Implications for the Future. Weinheim, Germany: Wiley-VCH.

Fryxell GE, Cao GZ(2007). Environmental Applications of Nanomaterials: Synthesis, Sorbents and Sensors. Hackensack: World Scientific Pub. Co. Inc.

Fulekar MH (2010). Nanotechnology in agriculture and food industry. In: Nanotechnology: Importance and Applications. New Delhi, India: I. K. International Publishing House Pvt Ltd: 139-157.

Gajbhiye M, Kesharwani J, Ingle A, Gade A, Rai M (2009). Fungus-mediated synthesis of silver nanoparticles and their activity against pathogenic fungi in combination with fluconazole. Nanomedicine; 5(4): 382-386.

Galadima A. and O Muraza (2015). In situ fast pyrolysis of biomass with zeolite catalysts for bioaromatics/ gasoline production: A review. Energy Conversion and Management, 105: 338-354.

Gandotra P, R K Jha, S Jain (2017). A survey on deviceto-device (D2D) communication: Architecture and security issues. Journal of Network and Computer Applications, 78: 9-29.

García A, Gonzalez Alriols M, Labidi J (2014). Evaluation of different lignocellulosic raw materials as potential alternative feedstocks in biorefinery processes. Ind Crops Prod 53: 102-110.

García A., J Labidi, M N Belgacem, J Bras (2016). The nanocellulose biorefinery: woody versus herbaceous agricultural wastes for NCC production. Cellulose, DOI: 10.1007/s10570-016-1144-2.

García-Gómez C., M. Babin, A. Obrador, J. M. Álvarez and M. D. Fernández (2015). Integrating ecotoxicity and chemical approaches to compare the effects of $\mathrm{ZnO}$ nanoparticles, $\mathrm{ZnO}$ bulk, and $\mathrm{ZnCl}_{2}$ on plants and microorganisms in a natural soil. Environ Sci Pollut Res 22: 16803-16813. DOI: 10.1007/s11356-015-4867-y

Ge C., Y Chai, H Wang, M Kan (2016). Ocean acidification: One potential driver of phosphorus eutrophication. Marine Pollution Bulletin, http:// dx.doi.org/10.1016/j.marpolbul.2016.12.016

Georgi A, A Schierz, K Mackenzie, F-D Kopinke (2015). Colloidal activated carbon for in-situ groundwater remediation - Transport characteristics and adsorption of organic compounds in water-saturated 
sediment columns. Journal of Contaminant Hydrology, 179: 76-88.

Geranio L., Heuberger, M., Nowack, B. (2009). The behavior of silver nanotextiles during washing. Environ. Sci. Technol. 43: 8113-8118.

Ghahremani A, Akbari K, Yousefpour M, Ardalani H (2014). Effect of Health Education Based on the Protection Motivation Theory on Malaria Preventive Behaviors in Rural Households of Kerman, Iran Int J Pharm Res Schol. 3: 235-241.

Ghasemi E., A Heydari, M Sillanpää (2017). Superparamagnetic $\mathrm{Fe}_{3} \mathrm{O}_{4} @$ EDTA nanoparticles as an efficient adsorbent for simultaneous removal of $\mathrm{Ag}(\mathrm{I}), \mathrm{Hg}(\mathrm{II}), \mathrm{Mn}(\mathrm{II}), \mathrm{Zn}(\mathrm{II}), \mathrm{Pb}(\mathrm{II})$ and $\mathrm{Cd}(\mathrm{II})$ from water and soil environmental samples. Microchemical Journal, 131: 51-56.

Ghosh A, A K Nayak and A Pal (2016). Nano-ParticleMediated Wastewater Treatment: a Review. Curr Pollution Rep, DOI: 10.1007/s40726-016-0045-1

Gil-Díaz M., P. Pinilla, J. Alonso and M. C. Lobo (2017). Viability of a nanoremediation process in single or multi-metal(loid) contaminated soils. Journal of Hazardous Materials, 321: 812-819

Gil-Díaz M., S. Diez-Pascual, A. González, J. Alonso, E. Rodríguez-Valdés, J.R. Gallego, M.C. Lobo (2016). A nanoremediation strategy for the recovery of an As-polluted soil. Chemosphere, 149: 137-145

Gohar A A. and A Cashman (2016). A methodology to assess the impact of climate variability and change on water resources, food security and economic welfare. Agricultural Systems, 147: 51-64.

Gomes H. I., G. Fan, L. M. Ottosen, C. Dias-Ferreira and A. B. Ribeiro (2016). Nanoremediation Coupled to Electrokinetics for PCB Removal from Soil. In: A.B. Ribeiro et al. (eds.), Electrokinetics Across Disciplines and Continents, pp: 331 - 350. DOI: 10.1007/978-3-319-20179-5_17, Springer International Publishing Switzerland

Gonçalves J R (2016). The Soil and Groundwater Remediation with Zero Valent Iron Nanoparticles. Procedia Engineering, 143: 1268-1275

Gopinath K, Gowri S, Karthika V, Arumugam A (2014). Green synthesis of gold nanoparticles from fruit extract of Terminalia arjuna, for the enhanced seed germination activity of Gloriosa superb, $J$ Nanostruct Chem, 4: 1-11.

Green JM, Beestman GB (2007). Recently patented and commercialized formulation and adjuvant

Env. Biodiv. Soil Security Vol. 3 (2019) technology. Crop Protection; 26 (3): 320-327.

Gruère G, Narrod C, Abbott L (2011). Agriculture, Food, and Water Nanotechnologies for the Poor: Opportunities and Constraints. Policy Brief 19. Washington, DC: International Food Policy Research Institute; Available from http://www.ifpri. org/sites/default/files/publications/bp019.pdf

Gupta SM, Tripathi M (2011). A review of $\mathrm{TiO}_{2}$ nanoparticles, Chin. Sci. Bull, 56: 1639-1657.

Gupta VK, Agarwal S, Saleh TA (2011). Synthesis and characterization of alumina-coated carbon nanotubes and their application for lead removal. $J$ Hazardous Mater 185(1): 17-23.

Gupta A and J P Verma (2015). Sustainable bioethanol production from agro-residues: A review. Renewable and Sustainable Energy Reviews, 41: 550-567.

Guo Z., G Chen, G Zeng, M Yan, Z Huang, L Jiang, C Peng, J Wang, Z Xiao (2017). Are silver nanoparticles always toxic in the presence of environmental anions? Chemosphere, 171: 318323.

Hamza R A, O T Iorhemen, J H Tay (2016). Occurrence, impacts and removal of emerging substances of concern from wastewater. Environmental Technology \& Innovation, 5: 161-175

Han JY, Y J Kim, H Kim (2017). An integrative model of information security policy compliance with psychological contract: Examining a bilateral perspective. Computers \& Security, 66: 52-65.

Handford C E., M Dean, M Spence, M Henchion, C T. Elliott, K Campbell (2015). Awareness and attitudes towards the emerging use of nanotechnology in the agri-food sector. Food Control, 57: 24-34

Handy RD, Henry TB, Scown TM, Johnston BD, Tyler CR (2008). Manufactured nanoparticles: their uptake and effects on fish - a mechanistic analysis. Ecotoxicol, 17: 396-409.

Hasaneen MNA, Abdel-Aziz HMM, El-Bialy DMA, Omer AM(2014). Preparation of chitosan nanoparticles for loadingwith NPK. Afr J Biotech 13: 3158-3164.

Hedayati M., P Sharma, D Katyal and F Fagerlund (2016). Transport and retention of carbon-based engineered and natural nanoparticles through saturated porous media. J Nanopart Res 18: 57. DOI: $10.1007 / \mathrm{s} 11051-016-3365-6$ 
Hegde K., S K Brar, M Verma, R Y. Surampalli (2016). Current understandings of toxicity, risks and regulations of engineered nanoparticles with respect to environmental microorganisms. Nanotechnol. Environ. Eng. 1: 5. DOI: 10.1007/ s41204-016-0005-4

Hischemöller A, Nordmann J, Ptacek P, Mummenhoff $\mathrm{K}$, Haase M (2009). In-vivo imaging of the uptake of upconversion nanoparticles by plant roots. $J$ Biomed Nanotechnol 5(3): 278-284.

Holbrook RD, Murphy KE, Morrow JB, Cole KD (2008). Trophic transfer of nanoparticles in a simplified invertebrate food web. Nature Nanotech, 3: 352-355.

Holden P.A., Gardea-Torresdey, J.L., Klaessig, F., Turco, R.F., Mortimer, M., Hund-Rinke, K., et al. (2016). Considerations of environmentally relevant test conditions for improved evaluation of ecological hazards of engineered nanomaterials. Environ. Sci. Technol. 50: 6124-6145.

Holden P.A., Klaessig, F., Turco, R.F., Priester, J.H., Rico, C.M., Avila-Arias, H., et al. (2014). Evaluation of exposure concentrations used in assessing manufactured nanomaterial environmental hazards: are they relevant? Environ. Sci. Technol. 48: 10541-10551.

Holden P.A., Nisbet, R.M., Lenihan, H.S., Miller, R.J., Cherr, G.N., Schimel, J.P., et al. (2013). Ecological nanotoxicology: integrating nanomaterial hazard considerations across the subcellular, population, community, and ecosystems levels. Acc. Chem. Res. 46: 813-822.

Hong J, Peralta-Videa JR, Gardea-Torresdey J (2013). Nanomaterials in agricultural production: benefits and possible threats? In: Shamim N, Sharma VK. Sustainable Nanotechnology and the Environment: Advances and Achievements. Washington, DC: American Chemical Society, pp: 73-90.

Horsfall MJ, Abia AA, Spiff AI (2006). Kinetic studies on the adsorption of $\mathrm{Cd}^{2+}, \mathrm{Cu}^{2+}$ and $\mathrm{Zn}^{2+}$ ions from aqueous solution by cassava (Manihot esculenta cranz) tuber bark waste. Bioresour Technol 97: 283-291.

Hu X., D Li, Y Gao, L Mu, Q Zhou (2016). Knowledge gaps between nanotoxicological research and nanomaterial safety. Environment International, 94: 8-23.

Hussain Z, H E Thu, S-F Ng, S Khan, H Katas (2017). Nanoencapsulation, an efficient and promising approach to maximize wound healing efficacy of curcumin: A review of new trends and state-of-theart. Colloids and Surfaces B: Biointerfaces, 150: 223-241

Jacques M. T., J L. Oliveira, E V.R. Campos, L F. Fraceto, D S Ávila (2017). Safety assessment of nanopesticides using the roundworm Caenorhabditis elegans. Ecotoxicology and Environmental Safety, 139: 245-253.

Jin Y., W Liu, X Li, S Shen, S Liang, C Liu, L Shan (2016). Nano-hydroxyapatite immobilized lead and enhanced plant growth of ryegrass in a contaminated soil. Ecological Engineering, 95: 25-29.

Jo YK, Kim BH, Jung G (2009). Antifungal activity of silver ions and nano-particles on phytopathogenic fungi. Plant Dis 93(10): 1037-1043.

Jones PBC (2006). A Nanotech Revolution in Agriculture and the Food Industry. Blacksburg, VA: Information Systems for Biotechnology; Available from: http://www.isb.vt.edu/articles/jun0605.htm. Accessed April 19, 2014.

Jyoti A and R S Tomar (2016). Detection of pathogenic bacteria using nanobiosensors. Environ Chem Lett, DOI: 10.1007/s10311-016-0594-y

Kah M, Beulke S, Tiede K, Hofmann T (2013). Nanopesticides: state of knowledge, environmental fate, and exposure modeling. Crit Rev Environ Sci Technol; 43(16): 1823-1867.

Kah M., Hofmann, T. (2014). Nanopesticide research: Current trends and future priorities. Environment International, 63: 224-235.

Kah M., P Machinski, P Koerner, K Tiede, R Grillo, L. F. Fraceto and T. Hofmann (2014). Analysing the fate of nanopesticides in soil and the applicability of regulatory protocols using a polymer-based nanoformulation of atrazine. Environ Sci Pollut Res 21: 11699-11707. DOI: 10.1007/s11356-0142523-6

Kailasa S K and J V. Rohit (2017). Tuning of gold nanoparticles analytical applications with nitro and hydroxy benzylindole-dithiocarbamates for simple and selective detection of terbufos and thiacloprid insecticides in environmental samples. Colloids and Surfaces A: Physicochemical and Engineering Aspects, 515: 50-61

Kallel F, Bettaieb F, Khiari R, Garcia A, Bras J, Chaabouni SE (2016). Isolation and structural characterization of cellulose nanocrystals extracted from garlic straw residues. Ind Crops Prod 87: 
287-296.

Kang S., X Hao, T Du, L Tong, X Su, H Lu, X Li, Z Huo, S Li, R Ding (2017). Improving agricultural water productivity to ensure food security in China under changing environment: From research to practice. Agricultural Water Management, 179: 5-17.

Karimi J. and S. Mohsenzadeh (2016). Effects of Silicon Oxide Nanoparticles on Growth and Physiology of Wheat Seedlings. Russian Journal of Plant Physiology, 63 (1): 119-123.

Kasana R C, N R Panwar, R K Kaul and P Kumar (2016). Copper Nanoparticles in Agriculture: Biological Synthesis and Antimicrobial Activity. In: S. Ranjan et al. (eds.), Nanoscience in Food and Agriculture 3, Sustainable Agriculture Reviews 23, DOI: 10.1007/978-3-319-48009-1_5, Springer International Publishing Switzerland

Khalil A M.E., O Eljamal, T W.M. Amen, Y Sugihara, N Matsunaga (2017). Optimized nano-scale zerovalent iron supported on treated activated carbon for enhanced nitrate and phosphate removal from water. Chemical Engineering Journal, 309: 349365

Khan M. N, M. Mobin, Z K Abbas, K A. AlMutairi, Z H. Siddiqui (2017). Role of nanomaterials in plants under challenging environments. Plant Physiology and Biochemistry, 110: 194-209.

Khan N. S., A K. Dixit and R Mehta (2016). Nanoparticle Toxicity in Water, Soil, Microbes, Plant and Animals. In: S. Ranjan et al. (eds.), Nanoscience in Food and Agriculture 2, Sustainable Agriculture Reviews 21, DOI: 10.1007/978-3-319-39306-3_9, Springer International Publishing Switzerland

Khan TA, Sharma S, Ali I (2011). Adsorption of rhodamine $\mathrm{b}$ dye from aqueous solution onto acid activated mango (Magnifera indica) leaf powder: equilibrium, kinetic and thermodynamic studies. $J$ Toxicol Environ Health Sci 3(10): 286-297

Khandelwal N, R S. Barbole, S S. Banerjee, G P. Chate, A V. Biradar, J J. Khandare, A P. Giri (2016). Budding trends in integrated pest management using advanced micro- and nano-materials: Challenges and perspectives. Journal of Environmental Management, 184 (Part 2): 157-169

Khani H, Rofouei MK, Arab P, Gupta VK, Vafaei Z (2010). Multiwalled carbon nanotubes-ionic liquid-carbon paste electrode as a super selectivity sensor: Application to potentiometric monitoring of mercury ion (II). J Hazard Mater 183: 402-409.

Env. Biodiv. Soil Security Vol. 3 (2019)
Khot L R., S Sankaran, J M Maja, R Ehsani, E. W. Schuster (2012). Applications of nanomaterials in agricultural production and crop protection: A review. Crop Protection, 35: 64-70.

Koch A (2017). Soil Security for Agricultural Productivity: The Policy Disconnect and a Promising Future. In: D.J. Field et al. (eds.), Global Soil Security, Progress in Soil Science, pp: 425 - 435. DOI: 10.1007/978-3-319-43394-3 39, Springer International Publishing Switzerland

Koch A, McBratney AB, Adams M, Field DJ, Hill R, Lal R, Abbott L, Angers D, Baldock J, Barbier E, Bird M, Bouma J, Chenu C, Crawford J, Flora CB, Goulding K, Grunwald S, Jastrow J, Lehmann J, Lorenz K, Minasny B, Morgan C, O’Donnell A, Parton W, Rice CW, Wall DH, Whitehead D, Young I, Zimmermann M (2013). Soil security: solving the global soil crisis. Glob Policy 4(4): 434-441

Koch A, McBratney AB, Lal R (2012). Global soil week: put soil security on the global agenda. Nature 492: 186

Kök F. N. (2016). Bionanotechnology: Lessons from Nature for Better Material Properties. In: H. Ünlü et al. (eds.), Low-Dimensional and Nanostructured Materials and Devices, Nano Science and Technology, DOI: 10.1007/978-3-319-25340-4_21, Springer International Publishing Switzerland

Kole C, D. S Kumar and M. V. Khodakovskaya (2016). Plant Nanotechnology: Principles and Practices. DOI: $\quad 10.1007 / 978-3-319-42154-4$, Springer International Publishing

Kumar A, Pandey AK, Singh SS, Shanker R, Dhawan A (2011a). Cellular uptake and mutagenic potential of metal oxide nanoparticles in bacterial cells. Chemosphere, 83: 1124-1132.

Kumar A, Pandey AK, Singh SS, Shanker R, Dhawan $\mathrm{A}$ (2011b). Engineered $\mathrm{ZnO}$ and $\mathrm{TiO} 2$ nanoparticles induce oxidative stress and DNA damage leading to reduced viability of Escherichia coli. Free Radical Biology \& Medicine, 51: 1872-1881.

Kumar A, Pandey AK, Singh SS, Shanker R, Dhawan A (2011c). Cellular response to metal oxide nanoparticles in bacteria. Journal of Biomedical Nanotechnology, 7: 102-103.

Kumar B, Kumar U (2014). Removal of malachite green and crystal violet dyes from aqueous solution with bio-materials: a review. Glo J Res Eng 14(4): $51-60$.

Kumar V, P Guleria and S K Mehta (2016). 
Nanoparticles to Sense Food Quality. In: S. Ranjan et al. (eds.), Nanoscience in Food and Agriculture 3, Sustainable Agriculture Reviews 23, DOI: 10.1007/978-3-319-48009-1_6, Springer International Publishing Switzerland

Kuppusamy S, P Thavamani, K Venkateswarlu, Y B Lee, R Naidu, M Megharaj (2017). Remediation approaches for polycyclic aromatic hydrocarbons (PAHs) contaminated soils: Technological constraints, emerging trends and future directions. Chemosphere, 168: 944-968.

Kuppusamy S., T Palanisami, M Megharaj, K Venkateswarlu and R. Naidu (2016). In-Situ Remediation Approaches for the Management of Contaminated Sites: A Comprehensive Overview. In: P. de Voogt (ed.), Reviews of Environmental Contamination and Toxicology Volume 236, Reviews of Environmental Contamination and Toxicology 236, pp: 1 - 115. DOI: 10.1007/978-3319-20013-2_1, Springer International Publishing Switzerland

Kurbanoglu S., S A. Ozkan, A Merkoçi (2017). Nanomaterials-based enzyme electrochemical biosensors operating through inhibition for biosensing applications. Biosensors and Bioelectronics, $\quad \mathrm{http} / / / \mathrm{dx}$. doi.org/10.1016/j. bios.2016.09.102

Kuswandi B (2016). Nanotechnology in Food Packaging. In: S. Ranjan et al. (eds.), Nanoscience in Food and Agriculture 1, Sustainable Agriculture Reviews 20, pp: 151 - 183. DOI: 10.1007/978-3319-39303-2_6, Springer International Publishing Switzerland

Kwak J. Il, Y-J An (2016). Trophic transfer of silver nanoparticles from earthworms disrupts the locomotion of springtails (Collembola). Journal of Hazardous Materials, 315: 110-116.

Lai F, Wissing SA, Mller RH, Fadda AM (2006). Artemisia arborescens L. essential oil loaded, solid lipid nanoparticles for potential agricultural application: Preparation and characterization. AAPS Pharm Sci Tech 7: 1-2.

Lal R (2008). Promise and limitations of soils to minimize climate change, J. Soil Water Conserv. 63: $113 \mathrm{~A}-118 \mathrm{~A}$.

Lal R, D Kraybill, D O. Hansen, B R Singh, T Mosogoya and L O Eik (2016). Climate Change and Multi-Dimensional Sustainability in African Agriculture: Climate Change and Sustainability in Agriculture. DOI: 10.1007/978-3-319-41238-2,
Springer International Publishing

Lal R. (2009). Soils and world food security. Soil and Tillage Research, 102 (1): 1-4

Lamsal K, Kim SW, Jung JH, Kim YS, Kim KS, Lee YS (2011). Inhibition effects of silver nanoparticles against powdery mildews on cucumber and pumpkin. Mycobiology, 39(1): 26-32.

Lee H V and J C Juan (2017). Nanocatalysis for the Conversion of Nonedible Biomass to Biogasoline via Deoxygenation Reaction. In: M. Rai, S.S. da Silva (eds.), Nanotechnology for Bioenergy and Biofuel Production, Green Chemistry and Sustainable Technology, pp: 301 - 323. DOI: 10.1007/978-3-319-45459-7_13, Springer International Publishing AG

Lee J., M Wipf, L Mu, C Adams, J Hannant, M A. Reed (2017). Metal-coated microfluidic channels: An approach to eliminate streaming potential effects in nano biosensors. Biosensors and Bioelectronics, 87: 447-452.

Lee R. G. and E. Stokes (2016). Material Uncertainty: Nanomaterials, Regulation and Symbolic Legislation. In: B. van Klink et al. (eds.), Symbolic Legislation Theory and Developments in Biolaw, Legisprudence Library 4, pp: 237 - 252. DOI: 10.1007/978-3-319-33365-6_14, Springer International Publishing Switzerland

Lewis K. L., P DeLaune and W Keeling (2017). Securing Our Soil in Intensive Monoculture Cropping Systems. In: D.J. Field et al. (eds.), Global Soil Security, Progress in Soil Science, pp: 145 - 151. DOI 10.1007/978-3-319-43394-3_13, Springer International Publishing Switzerland

Li Q. and Sun (2016). Recent advances in the organic solution phase synthesis of metal nanoparticles and their electrocatalysis for energy conversion reactions. Nano Energy, 29: 178-197

Lin S., Reppert J., Hu Q., Hudson J. S., Reid M. L., Ratnikova T. A., Rao A. M., Luo H., Ke P. C. (2009). Uptake, translocation, and transmission of carbon nanomaterials in rice plants. Small, 5: 11281132.

Liu P-H, M Wen, C-S Tan, M Navlani-García, Y Kuwahara, K Mori, H Yamashita and L-J Chen (2017). Surface plasmon resonance enhancement of production of $\mathrm{H} 2$ from ammonia borane solution with tunable $\mathrm{Cu}_{2-\mathrm{x}} \mathrm{S}$ nanowires decorated by $\mathrm{Pd}$ nanoparticles. Nano Energy, 31: 57-63.

Liu R. And Lal R. (2015) Potentials of engineered Env. Biodiv. Soil Security Vol. 3 (2019) 
nanoparticles as fertilizers for increasing agronomic productions. Sci. Total Environ. 514: 131-139.doi: 10.1016/j.scitotenv.2015.01.104.

Loganathan C. and S. A. John (2017). Naked eye and spectrophotometric detection of chromogenic insecticide in aquaculture using amine functionalized gold nanoparticles in the presence of major interferents. Spectrochimica Acta Part A: Molecular and Biomolecular Spectroscopy, 173: $837-842$

Lopez-Moreno M. L., De La Rosa G., HernandezViezcas J. A., Castillo-Michel H., Botez C. E., Peralta-Videa J. R., Gardea-Torresdey J. L. (2010). Evidence of the differential biotransformation and genotoxicity of $\mathrm{ZnO}$ and $\mathrm{CeO} 2$ nanoparticles on soybean (Glycine max) plants. Environ Sci Technol, 44: 7315-7320.

Lu CM, Zhang CY, Wen JQ, Wu GR \& Tao MX (2002). Research of the effect of nanometer materials on germination and growth enhancement of Glycine max and its mechanism, Soybean Sci. 21: 168-172.

Ma M-G, B Liu and L-Y Meng (2017). Applications of Carbon-Based Nanomaterials in Biofuel Cell. In: M. Rai, S.S. da Silva (eds.), Nanotechnology for Bioenergy and Biofuel Production, Green Chemistry and Sustainable Technology, pp: $39-$ 59. DOI: 10.1007/978-3-319-45459-7_3, Springer International Publishing AG

Macer D. (2014). Nanotechnology and Biodiversity. In: B. Gordijn and A.M. Cutter (eds.), In Pursuit of Nanoethics, The International Library of Ethics, Law and Technology 10, pp: 73 - 87. DOI: 10.1007/978-1-4020-6817-1_6, Springer Science + Business Media Dordrecht

Madhumitha G., J. Fowsiya and S M Roopan (2016). Nanoparticles for Agriculture: Synthesis, Classification and Characterization. In: S. Ranjan et al. (eds.), Nanoscience in Food and Agriculture 3, Sustainable Agriculture Reviews 23, pp: $99-$ 129. DOI: 10.1007/978-3-319-48009-1_4, Springer International Publishing Switzerland

Mahmood T, Hussain ST (2010). Nanobiotechnology for the production of biofuels from spent tea. African Journal of Biotechnology 9(6): 858-868.

Maiti R and A Kumari (2016). Physiological Basis of Crop Productivity. In: R.K. Maiti et al. (eds.), Bioresource and Stress Management, DOI: 10.1007/978-981-10-0995-2_6, Springer Science + Business Media Singapore
Majumdar S., J R. Peralta-Videa, J Trujillo-Reyes, Y Sun, A C. Barrios, G Niu, J P. Flores- Margez, J L. Gardea-Torresdey (2016). Soil organic matter influences cerium translocation and physiological processes in kidney bean plants exposed to cerium oxide nanoparticles. Science of The Total Environment, 569-570: 201-211.

Malekian A., D Hayati and N Aarts (2017). Conceptualizations of water security in the agricultural sector: Perceptions, practices, and paradigms. Journal of Hydrology, 544: 224-232. doi: http://dx.doi.org/ 10.1016/j.jhydrol.2016.11.026

Manceau A, Nagy KL, Marcus MA, et al. (2008). Formation of metallic copper nanoparticles at the soil-root interface. Environ Sci Technol. 42(5): 1766-1772.

Mani P K and S Mondal (2016). Agri-nanotechniques for Plant Availability of Nutrients. In: C. Kole et al. (eds.), Plant Nanotechnology, pp: 263 - 303. DOI: 10.1007/978-3-319-42154-4_11, Springer International Publishing Switzerland

Manjunatha S. B., D. P. Biradar and Y. R. Aladakatti (2016). Nanotechnology and its applications in agriculture: A review. J. Farm Sci., 29(1): 1-13.

Markovska N, N Duić, B V Mathiesen, Z Guzović, A Piacentino, H Schlör, H Lund (2016). Addressing the main challenges of energy security in the twenty-first century e Contributions of the conferences on Sustainable Development of Energy, Water and Environment Systems. Energy 115 (Part 3): 1504-1512. http://dx.doi.org/ 10.1016/j. energy.2016.10.086

Maskos M., R.H. Stauber (2017). Characterization of Nanoparticles in Biological Environments. Reference Module in Materials Science and Materials Engineering, http://dx.doi.org/10.1016/ B978-0-12-803581-8.09823-4

Mastronardi E., P Tsae, X Zhang, C Monreal and M C. De Rosa (2015). Strategic Role of Nanotechnology in Fertilizers: Potential and Limitations. In: M. Rai et al. (eds.), Nanotechnologies in Food and Agriculture, pp: 25 - 67. DOI: 10.1007/978-3319-14024-7_2, Springer International Publishing Switzerland

Mattsson M.-O. and M. Simkó (2016). The changing face of nanomaterials: Risk assessment challenges along the value chain. Regulatory Toxicology and Pharmacology, http://dx.doi.org/10.1016/j. yrtph.2016.12.008 
McBratney A B., D J. Field, C L. S. Morgan and L. E. Jarrett (2017). Soil Security: A Rationale. In: D.J. Field et al. (eds.), Global Soil Security, Progress in Soil Science, pp: 3 - 14. DOI: 10.1007/978-3319-43394-3_1, Springer International Publishing Switzerland

McBratney A, Field DJ, Koch A(2014). The dimensions of soil security. Geoderma 213: 203-213. http:// dx.doi.org/10.1016/j.geoderma.2013.08.013

McBratney A. B. and L. E. Jarrett (2017). Securitisation. In: D.J. Field et al. (eds.), Global Soil Security, Progress in Soil Science, pp: 437 - 441. DOI: 10.1007/978-3-319-43394-3_40, Springer International Publishing Switzerland

McCarl B A. (2017). Economics, Energy, Climate Change, and Soil Security. In: D.J. Field et al. (eds.), Global Soil Security, Progress in Soil Science, pp: 195 - 205. DOI: 10.1007/978-3-319-43394-3_17, Springer International Publishing Switzerland

Mekki A., F Arous, F Aloui S Sayadi (2016). Treatment and Valorization of Agro-wastes as Biofertilizers Waste Biomass Valor, DOI: 10.1007/s12649-0169620-3

Michálková Z, M Komárek, V Veselská and S Č́íhalová (2016). Selected $\mathrm{Fe}$ and $\mathrm{Mn}$ (nano)oxides as perspective amendments for the stabilization of As in contaminated soils. Environ Sci Pollut Res 23: 10841-10854. DOI: 10.1007/s11356-016-6200-9

Mignani S, M Bryszewska, M Zablocka, B KlajnertMaculewicz, J Cladera, D Shcharbin, J-P Majoral (2017). Can dendrimer based nanoparticles fight neurodegenerative diseases? Current situation versus other established approaches. Progress in Polymer Science, 64: 23-51

Miseljic M. and S. I. Olsen (2014). Life-cycle assessment of engineered nanomaterials: a literature review of assessment status. J Nanopart Res 16: 2427 . DOI $10.1007 / \mathrm{s} 11051-014-2427-\mathrm{x}$

Mottier A., F Mouchet, É Pinelli, L Gauthier, E Flahaut (2017). Environmental impact of engineered carbon nanoparticles: from releases to effects on the aquatic biota. Current Opinion in Biotechnology, 46: 1-6.

Mukhopadhyay S S and N Kaur (2016). Nanotechnology in Soil-Plant System. In: C. Kole et al. (eds.), Plant Nanotechnology, pp: 329 - 348. DOI: 10.1007/9783-319-42154-4_13, Springer International Publishing Switzerland

Murday J.S., Siegel, R.W., Stein, J., Wright, J.F. (2009).
Translational nanomedicine: status assessment and opportunities. Nanomed. Nanotechnol. 5: 251-273.

Murphy B. (2017). Testing the Links Between Soil Security, Sustainable Land Management Practices and Land Evaluation. In: D.J. Field et al. (eds.), Global Soil Security, Progress in Soil Science, pp: 87 - 97. DOI 10.1007/978-3-319-43394-3 8, Springer International Publishing Switzerland

Naderi MR, Danesh-Shahraki A (2013). Nanofertilizers and their roles in sustainable agriculture. Int J Agri Crop Sci.; 5(19): 2229-2232.

Nag-Chowdhury S., H. Bellegou, I. Pillin, M. Castro, P. Longrais, J.F. Feller (2016). Non-intrusive health monitoring of infused composites with embedded carbon quantum piezo-resistive sensors. Composites Science and Technology, 123: 286-294

Nair R, Varghese SH, Nair BG, Maekawa T, Yoshida Y, Kumar DS (2010). Nanoparticulate material delivery to plants. Plant Sci 179: 154-163.

Nanda S., J Isen, A K. Dalai, J A. Kozinski (2016). Gasification of fruit wastes and agro-food residues in supercritical water. Energy Conversion and Management, 110: 296-306

Navarro E, Baun A, Behra R, Hartmann NB, Filser J, Miao AJ, Quigg A, Santschi PH, Sigg L(2008). Environmental behavior and ecotoxicity of engineered nanoparticles to algae, plants, and fungi. Ecotoxicol 17: 372-386.

Nawaz A. and T. W. Wong (2017). Microwave as skin permeation enhancer for transdermal drug delivery of chitosan-5-fluorouracil nanoparticles. Carbohydrate Polymers, 157: 906-919

Nazarenko Y., Zhen, H.J., Han, T., Lioy, P.J., Mainelis, G. (2012). Potential for inhalation exposure to engineered nanoparticles from nanotechnologybased cosmetic powders. Environ. Health Perspect. 120: $885-892$.

Ningchuan F, Xueyi G, Sha L (2009). Adsorption study of copper (II) by chemically modified orange peel. J Hazard Mater 164(2):1286-1292.

Nuhoff-Isakhanyan G, E F.M. Wubben, O S.W.F. Omta and S Pascucci (2017). Network structure in sustainable agro-industrial parks. Journal of Cleaner Production, 141: 1209-1220.

Oleszczuk P and M Kołtowski (2017). Effect of coapplication of nano-zero valent iron and biochar on the total and freely dissolved polycyclic aromatic hydrocarbons removal and toxicity of contaminated 
soils. Chemosphere, 168: 1467-1476.

Oomen A.G., Bos, P.M.J., Fernandes, T.F., Hund-Rinke, K., Boraschi, D., Byrne, H.J., et al. (2014). Concerndriven integrated approaches to nanomaterial testing and assessment - report of the nanosafety cluster working group 10. Nanotoxicology 8: 334348.

Otles S, Yalcin B (2010). Nano-biosensors as new tool for detection of food quality and safety. $\log$ Forum; 6(4):67-70.

Pallavi, C. M. Mehta, R Srivastava, S Arora, A. K. Sharma (2016). Impact assessment of silver nanoparticles on plant growth and soil bacterial diversity. 3 Biotech 6: 254. DOI: 10.1007/s13205016-0567-7

Pandey S., K Giri, R. Kumar, G Mishra and R. Raja Rishi (2016). Nanopesticides: Opportunities in Crop Protection and Associated Environmental Risks. Proc. Natl. Acad. Sci., India, Sect. B Biol. Sci., DOI: 10.1007/s40011-016-0791-2,

Panpatte D. G., Y. K. Jhala, H. N. Shelat and R. V. Vyas (2016). Nanoparticles: The Next Generation Technology for Sustainable Agriculture. In: D.P. Singh et al. (eds.), Microbial Inoculants in Sustainable Agricultural Productivity, pp: 289 - 300. DOI: 10.1007/978-81-322-2644-4_18, Springer India

Panwar J, Jain N, Bhargaya A, Akhtar MS, Yun YS (2012). Positive effect of zinc oxide nanoparticels on tomato plants: A step towards developing "Nano-fertilizers" 01/2012; Proceeding of 3rd International Conference on Environmental Research and Technology (ICERT); May 30-June 1; Penang, Malaysia.

Park HJ, Kim SH, Kim HJ, Choi SH (2006). A new composition of nanosized silica-silver for control of various plant diseases. Plant Pathol J. 22(3): 295-302.

Park J Y., S Lim and K. Park (2014). A new approach for determination of fouling potential by colloidal nanoparticles during reverse osmosis (RO) membrane filtration of seawater. $J$ Nanopart Res 15: 63-71. DOI: 10.1007/978-3-319-05041-6

Patel PD (2002). (Bio) sensors for measurement of analytes implicated in food safety: A review. TrAC Trends in Analytical Chemistry, 21: 96-115.

Patil P. O., P. V. Bhandari, P. K. Deshmukh, S. S. Mahale, A. G. Patil, H R. Bafna, K V. Patel and S B. Bari (2017). Green fabrication of graphene- based silver nanocomposites using agro-waste for sensing of heavy metals. Res Chem Intermed, DOI: 10.1007/s11164-016-2844-9

Patra A. K., T Adhikari and A. K. Bhardwaj (2016). Enhancing Crop Productivity in Salt-Affected Environments by Stimulating Soil Biological Processes and Remediation Using Nanotechnology. In: J.C. Dagar et al. (eds.), Innovative Saline Agriculture, pp: 83 - 103. DOI: 10.1007/978-81322-2770-0_4, Springer India

Pawlett M., K Ritz, R A. Dorey, S Rocks, J Ramsden, J A. Harris (2013). The impact of zero-valent iron nanoparticles upon soil microbial communities is context dependent. Environ Sci Pollut Res 20: 1041-1049. DOI: 10.1007/s11356-012-1196-2.

Pérez-de-Luque A, Rubiales D (2009). Nanotechnology for parasitic plant control. Pest Manag Sci; 65(5): $540-545$

Peters R J.B., H Bouwmeester, S Gottardo, V Amenta, M Arena, P Brandhoff, H J.P. Marvin, A Mech, F B Moniz, L Q Pesudo, H Rauscher, R Schoonjans, A K. Undas, M V Vettori, S Weigel, K Aschberger (2016). Nanomaterials for products and application in agriculture, feed and food. Trends in Food Science \& Technology, 54: 155-164

Petosa A R, F Rajput, O Selvam, C Öhl, N Tufenkji (2017). Assessing the transport potential of polymeric nanocapsules developed for crop protection. Water Research, 111: 10-17

Petosa A R, F Rajput, O Selvam, C Öhl, N Tufenkji (2017). Assessing the transport potential of polymeric nanocapsules developed for crop protection. Water Research, 111: 10-17

Pokhrel LR, Dubey B (2013). Evaluation of developmental responses of two crop plants exposed to silver and zinc oxide nanoparticles, Sci. Tot. Environ., 321-332.

Polloni-Silva J, A Valdehita, R Fracácio, J M. Navas (2017). Remediation efficiency of three treatments on water polluted with endocrine disruptors: Assessment by means of in vitro techniques. Chemosphere, (in press)

Powell MC, Kanarek MS (2006). Nanomaterial health effects-part 1: background and current knowledge. Wisc Med J, 105: 16-20 [http://www. wisconsinmedicalsociety.org/_WMS/publications/ wmj/pdf/105/2/16.pdf]

Pramanik S and G Pramanik (2016). Nanotechnology for Sustainable Agriculture in India. In: S. Ranjan et 
al. (eds.), Nanoscience in Food and Agriculture 3, Sustainable Agriculture Reviews 23, pp: 243 - 280. DOI: 10.1007/978-3-319-48009-1_10, Springer International Publishing Switzerland

Prasad R, Kumar V, Prasad KS (2014). Nanotechnology in sustainable agriculture: present concerns and future aspects. Afr J Biotechnol. 13(6): 705-713.

Prasad R, Bagde US, Varma A (2012). Intellectual property rights and agricultural biotechnology: an overview. Afr J Biotechnol 11(73): 13746-13752

Prashantha Kumar T.K.M., T R. Mandlimath, P. Sangeetha, S.K. Revathi and S. K. Ashok Kumar (2016). Selective Removal of Nitrate and Phosphate from Wastewater Using Nanoscale Materials. In: S. Ranjan et al. (eds.), Nanoscience in Food and Agriculture 3, Sustainable Agriculture Reviews 23, DOI 10.1007/978-3-319-48009-1_8, Springer International Publishing Switzerland

Priebe M, J Widmer, N S Löwa, S-L Abram, I Mottas, A-K Woischnig, P S. Brunetto, N Khanna, C Bourquin, K M. Fromm (2017). Antimicrobial silver-filled silica nanorattles with low immunotoxicity in dendritic cells. Nanomedicine: Nanotechnology, Biology and Medicine, 13 (1): 1122

Priester J H., S C Moritz, K Espinosa, Y Ge, Y Wang, R M. Nisbet, J P. Schimel, A. S Goggi, J L. GardeaTorresdey, P A. Holden (2017). Damage assessment for soybean cultivated in soil with either $\mathrm{CeO} 2$ or $\mathrm{ZnO}$ manufactured nanomaterials. Science of The Total Environment, 579: 1756-1768.

Pu W., H Zhao, L Wu and X Zhao (2015). A colorimetric method for the determination of xanthine based on the aggregation of gold nanoparticles. Microchim Acta 182: 395-400. DOI: 10.1007/s00604-014$1342-2$

Pulimi M. and S. Subramanian (2016). Nanomaterials for Soil Fertilisation and Contaminant Removal. In: S. Ranjan et al. (eds.), Nanoscience in Food and Agriculture 1, Sustainable Agriculture Reviews 20, pp: 229 - 246. DOI: 10.1007/978-3-319-393032_8, Springer International Publishing Switzerland

Purkayastha M D and A K Manhar (2016). Nanotechnological Applications in Food Packaging, Sensors and Bioactive Delivery Systems. In: S. Ranjan et al. (eds.), Nanoscience in Food and Agriculture 2, Sustainable Agriculture Reviews 21, DOI: 10.1007/978-3-319-39306-3_3, Springer International Publishing Switzerland
Qu X., Alvarez, P.J.J., Li, Q. (2013). Applications of nanotechnology in water and wastewater treatment. Water Res. 47 (12): 3931-3946.

Rabbani M. M., I Ahmed and S-J Park (2016). Application of Nanotechnology to Remediate Contaminated Soils. In: H. Hasegawa et al. (eds.), Environmental Remediation Technologies for Metal Contaminated Soils, pp: 219 - 229. DOI: 10.1007/978-4-431-55759-3_10, Springer Japan

Ragaei M, Sabry A. H (2014). Nanotechnology for insect pest control. Int J Sci Environ Technol 3: $528-545$

Rai M, C Ribeiro, L Mattoso and N Duran (2015). Nanotechnologies in Food and Agriculture. DOI: 10.1007/978-3-319-14024-7, Springer International Publishing Switzerland

Rai M, Ingle A(2012) Role of nanotechnology in agriculture with special reference to management of insect pests. Appl Microbiol Biotechnol.; 94(2): 287-293.

Rai M. and S S da Silva (2017). Nanotechnology for Bioenergy and Biofuel Production. Green Chemistry and Sustainable Technology Series, DOI: $\quad 10.1007 / 978-3-319-45459-7$, Springer International Publishing Switzerland

Rai V, Acharya S, Dey N. (2012). Implications of nanobiosensors in agriculture. $J$ Biomater Nanobiotchnol. 3: 315-324.

Ramnani P, N M. Saucedo, A Mulchandani (2016). Carbon nanomaterial-based electrochemical biosensors for label-free sensing of environmental pollutants. Chemosphere, 143: 85-98.

Rani M., U Shanker and V. Jassal (2017). Recent strategies for removal and degradation of persistent $\&$ toxic organo-chlorine pesticides using nanoparticles: A review. Journal of Environmental Management, 190: 208-222

Rao P J. and M M. Naidu (2016). Nanoencapsulation of Bioactive Compounds for Nutraceutical Food. In: S. Ranjan et al. (eds.), Nanoscience in Food and Agriculture 2, Sustainable Agriculture Reviews 21, pp: 129 - 156. DOI: 10.1007/978-3-319-393063_4, Springer International Publishing Switzerland

Rao S. and G S Shekhawat (2016). Phytotoxicity and oxidative stress perspective of two selected nanoparticles in Brassica juncea. 3 Biotech 6: 244. DOI: $10.1007 / \mathrm{s} 13205-016-0550-3$

Ray M., A Ray, S Dash, A Mishra, K. G Achary, S Nayak, 
S Singh (2017). Fungal disease detection in plants: Traditional assays, novel diagnostic techniques and biosensors. Biosensors and Bioelectronics, 87: 708723.

Read D. S., M Matzke, H. S. Gweon, L K. Newbold, L Heggelund, M D Ortiz, E Lahive, D Spurgeon and C Svendsen (2016). Soil pH effects on the interactions between dissolved zinc, non-nano- and nano-ZnO with soil bacterial communities. Environ Sci Pollut Res 23: 4120-4128. DOI: 10.1007/ s11356-015-4538-z

Reddy P.V.L., Hernandez-Viezcas, J.A., Peralta-Videa, J.R., Gardea-Torresdey, J.L. (2016). Lessons learned: are engineered nanomaterials toxic to terrestrial plants? Sci. Total Environ. 568: 470-479.

Rico C.M., Peralta-Videa, J.R., Gardea-Torresdey, J.L. (2015). Chemistry, biochemistry of nanoparticles, and their role in antioxidant defense system in plants. In: Siddiqui, M.H., Al-Whaibi, M.H., Mohammad, F. (Eds.), Nanotechnology and Plant Sciences. Springer International Publishing, pp. $1-17$

Rico CM, Majumdar S, Duarte-Gardea M, PeraltaVidea JR, Gardea-Torresdey JL (2011). Interaction of nanoparticles with edible plants and their possible implications in the food chain. J Agric Food Chem. 59(8): 3485-3498.

Rizwan M, S Ali, M F Qayyum, Y S Ok, M Adrees, $M$ Ibrahim, $M$ Zia-ur-Rehman, $M$ Farid, F Abbas (2017). Effect of metal and metal oxide nanoparticles on growth and physiology of globally important food crops: A critical review. Journal of Hazardous Materials, 322 (Part A): 2-16.

Samarajeewa A. D., J.R. Velicogna, J.I. Princz, R.M. Subasinghe, R.P. Scroggins, L.A. Beaudette (2017). Effect of silver nano-particles on soil microbial growth, activity and community diversity in a sandy loam soil. Environmental Pollution, 220 (Part A): 504-513.

Sarkar P., S Irshaan, S. Sivapratha and R Choudhary (2016). Nanotechnology in Food Processing and Packaging. In: S. Ranjan et al. (eds.), Nanoscience in Food and Agriculture 1, Sustainable Agriculture Reviews 20, pp: 185 - 227. DOI: 10.1007/978-3319-39303-2_7, Springer International Publishing Switzerland

Sarkar S, Datta SC, Biswas DR (2015). Overview of VOC emissions and chemistry from PTR-TOF-MS measurements during the SusKat-ABC campaign: high acetaldehyde, isopreneand isocyanic acid in wintertime air of the Kathmandu Valley. Proc Nat. Acad. Sci. B Biol Sci.; 85:415-421.

Sasson Y, Levy-Ruso G, Toledano O, Ishaaya I (2007). Nanosuspensions: emerging novel agrochemical formulations. In: Ishaaya I, Nauen R, Horowitz $\mathrm{AR}$, editors. Insecticides Design Using Advanced Technologies. Springer-Verlag Berlin Heidelberg $1-39$.

Sastry RK, Rao NH, Cahoon R, Tucker T (2007). Can nanotechnology provide the innovations for a second green revolution in Indian agriculture? NSF Nanoscale Science and Engineering Grantees Conference; December 3-6; Arlington, VA.

Sayes CM, Warheit DB (2009). Characterization of nanomaterials for toxicity assessment. Wiley Interdisciplinary Reviews. Nanomedicine and Nanobiotechnology, 1: 660-670.

Saylan Y., S Akgönüllü, D Çimen, A. Derazshamshir, N Bereli, F Yilmaz and A. Denizli (2017). Development of surface plasmon resonance sensors based on molecularly imprinted nanofilms for sensitive and selective detection of pesticides. Sensors and Actuators B: Chemical, 241: 446-454.

Schlich K, L Beule, K Hund-Rinke (2016). Single versus repeated applications of $\mathrm{CuO}$ and $\mathrm{Ag}$ nanomaterials and their effect on soil microflora. Environmental Pollution, 215: 322-330.

Schultz C., K Powell, A Crossley, K Jurkschat, P Kille, A. J Morgan, D Read, W Tyne, E Lahive, C Svendsen and D J. Spurgeon (2015). Analytical approaches to support current understanding of exposure, uptake and distributions of engineered nanoparticles by aquatic and terrestrial organisms Ecotoxicology 24: 239-261. DOI: 10.1007/s10646014-1387-3

Scrinis G, Lyons K (2007). The emerging nanocorporate paradigm: nanotechnology and the transformation of nature, food and agri-food systems. International Journal of Sociology of Food and Agriculture 15(2): 22-44.

Sekhon BS (2014). Nanotechnology in agri-food production: an overview. Nanotechnol Sci Appl 7: $31-53$

Seo J Y, M G. Kim, K Lee, Y-C Lee, J-G Na, S G Jeon, S B Park and Y-K Oh (2017). Multifunctional Nanoparticle Applications to Microalgal Biorefinery. In: M. Rai, S.S. da Silva (eds.), Nanotechnology for Bioenergy and Biofuel Production, Green Chemistry and Sustainable 
Technology, pp: 59 - 87. DOI: 10.1007/978-3-31945459-7_4, Springer International Publishing AG

Servin A D. and J. C. White (2016). Nanotechnology in agriculture: Next steps for understanding engineered nanoparticle exposure and risk. Nano Impact 1: 9-12. http://dx.doi.org/10.1016/j. impact.2015.12.002

Servin A. D., R De la Torre-Roche, H Castillo-Michel, L Pagano, J Hawthorne, C Musante, J Pignatello, M Uchimiya, J C. White (2017). Exposure of agricultural crops to nanoparticle $\mathrm{CeO} 2$ in biocharamended soil. Plant Physiology and Biochemistry, 110: $147-157$

Servin A., W Elmer, A Mukherjee, R De la TorreRoche, H Hamdi, J C. White, P Bindraban and C Dimkpa (2015). A review of the use of engineered nanomaterials to suppress plant disease and enhance crop yield. J Nanopart Res 17: 92. DOI: 10.1007/ s11051-015-2907-7

Shaikh P H, N Bin Mohd. Nor, A A Sahito, P Nallagownden, I Elamvazuthi, M.S. Shaikh (2016). Building energy for sustainable development in Malaysia: A review. Renewable and Sustainable Energy Reviews, http://dx.doi.org/10.1016/j. rser.2016.11.128

Shuai H-L, K-J Huang, W-J Zhang, X Cao, M-P Jia (2017). Sandwich-type microRNA biosensor based on magnesium oxide nanoflower and graphene oxide-gold nanoparticles hybrids coupling with enzyme signal amplification. Sensors and Actuators B: Chemical, 243: 403-411

Shulaker M.M., Hills, G., Patil, N., Wei, H., Chen, H.Y., Philip Wong, H.S., et al. (2013). Carbon nanotube computer. Nature 501: 526-530. doi:10.1038/ nature 12502

Siddiqui M H., M H. Al-Whaibi and F Mohammad (2015). Nanotechnology and Plant Sciences: Nanoparticles and Their Impact on Plants. DOI: 10.1007/978-3-319-14502-0, Springer International Publishing

Siddiqui M. H., M. H. Al-Whaibi, M. Firoz and M. Y. AlKhaishany (2015). Role of Nanoparticles in Plants In: M.H. Siddiqui et al. (eds.), Nanotechnology and Plant Sciences, pp: 19 - 35. DOI: 10.1007/978-3319-14502-0_2, Springer International Publishing Switzerland

Simonin M. and A Richaume (2015). Impact of engineered nanoparticles on the activity, abundance, and diversity of soil microbial communities: A review. Environ Sci Pollut Res 22: 13710-13723. DOI: $10.1007 / \mathrm{s} 11356-015-4171-\mathrm{x}$

Singh A. and S. M. Prasad (2016). Nanotechnology and its role in agro-ecosystem: a strategic perspective. Int. J. Environ. Sci. Technol., DOI: 10.1007/ s13762-016-1062-8

Singh D and A Kumar (2016). Impact of Irrigation Using Water Containing $\mathrm{CuO}$ and $\mathrm{ZnO}$ Nanoparticles on Spinach oleracea Grown in Soil Media. Bull Environ Contam Toxicol 97: 548-553. DOI: 10.1007/s00128-016-1872-x

Singh R, Shedbalkar UU, Wadhwani SA, Chopade BA (2015b). Bacteriagenic silver nanoparticles: synthesis, mechanism, and applications. Appl Microbiol Biotechnol. doi: 10.1007/ s00253-0156622-1.

Singh S., N Rathi, A Angal, P Parida and D Rautaray (2016). Biofortification of Food with Minerals and Vitamins Encapsulated in Silica. In: S. Ranjan et al. (eds.), Nanoscience in Food and Agriculture 2, Sustainable Agriculture Reviews 21, DOI: 10.1007/978-3-319-39306-3 5, Springer International Publishing Switzerland

Soni D, P K. Naoghare, S Saravanadevi and R A Pandey (2015). Release, Transport and Toxicity of Engineered Nanoparticles. In: D.M. Whitacre (ed.), Reviews of Environmental Contamination and Toxicology Volume 234, Reviews of Environmental Contamination and Toxicology 234, DOI: 10.1007/978-3-319-10638-0_1, Springer International Publishing Switzerland

Sonkaria S, Ahn SH, Khare V (2012). Nanotechnology and its impact on food and nutrition: A review. Recent Pat Food Nutr Agric. 4(1): 8-18.

Spanos G. and L Angelis (2016). The impact of information security events to the stock market: A systematic literature review. Computers \& Security, 58: $216-229$.

Sri Sindhura K., T. N. V. K. V. Prasad, P. Panner Selvam and O. M. Hussain (2014). Synthesis, characterization and evaluation of effect of phytogenic zinc nanoparticles on soil exo-enzymes Appl Nanosci 4: 819-827. DOI: 10.1007/s13204013-0263-4

Stadler T, Buteler M, Weaver DK (2010)Novel use of nano-structured alumina as an insecticide. Pest Manag Sci. 66(6): 577-579.

Subramanian KS, Manikandan A, Thirunavukkarasu M, Rahale CS (2015). Nano-fertilizers for balanced Env. Biodiv. Soil Security Vol. 3 (2019) 
crop nutrition. In: Ra M et al (eds) Nanotechnologies in Food and Agriculture. Springer International Publishing, Cham, pp 69-80. doi:10.1007/978-3319-14024-7 3

Suzuki RM, Andrade AD, Sousa JC, Rollemberg MC (2007). Preparation and characterization of activated carbon from rice bran. Bioresour Technol 98(10): 1986-1991.

Syberg K. and S F Hansen (2016). Environmental risk assessment of chemicals and nanomaterials: The best foundation for regulatory decision-making? Science of The Total Environment, 541: 784-794.

Tan IA, Ahmad AL, Hameed BH (2008). Adsorption of basic dye on high-surface -area activated carbon prepared from coconut husk: equilibrium, kinetic and thermodynamic studies. $J$ Hazard Mater 154: 337-347.

Tarafdar JC, Raliya R, Mahawar H, Rathore I (2014). Development of zinc nanofertilizer to enhance crop production in pearl millet (Pennisetum americanum), Agric Res 3(3): 257-262.

Tassi E., L. Giorgetti, E. Morelli, J.R. Peralta-Videa, J.L. Gardea-Torresdey, M. Barbafieri (2017). Physiological and biochemical responses of sunflower (Helianthus annuus L.) exposed to nano$\mathrm{CeO} 2$ and excess boron: Modulation of boron phytotoxicity. Plant Physiology and Biochemistry, 110: $50-58$

Taylor A. (2015). Large-Scale Land and Acquisitions in Tanzania: A Critical Analysis of Their Implications on Water Security. Dalhousie University Halifax, Nova Scotia

Terekhovaa V. A. and M. M. Gladkova (2013). Engineered Nanomaterials in Soil: Problems in Assessing Their Effect on Living Organisms. Eurasian Soil Science, 46 (12): 1203-1210

Thakur A K and R Maiti (2016). Recent Trends in Seed Science and Technology. In: R. K. Maiti et al. (eds.), Bioresource and Stress Management, pp: 257 - 276. DOI: 10.1007/978-981-10-0995-2_13, Springer Science + Business Media Singapore 2016

Thul S. T. and B. K. Sarangi (2015). Implications of Nanotechnology on Plant Productivity and Its Rhizospheric Environment. In: M.H. Siddiqui et al. (eds.), Nanotechnology and Plant Sciences, pp: 37 - 53. DOI: 10.1007/978-3-319-14502-0_3, Springer International Publishing Switzerland

Tolaymat T, A Genaidy, W Abdelraheem, D Dionysiou,
C Andersen (2017). The effects of metallic engineered nanoparticles upon plant systems: An analytic examination of scientific evidence. Science of The Total Environment, 579: 93-106

Toli A, K Chalastara, C Mystrioti, A Xenidis, N Papassiopi (2016). Incorporation of zero valent iron nanoparticles in the matrix of cationic resin beads for the remediation of $\mathrm{Cr}(\mathrm{VI})$ contaminated waters. Environmental Pollution, 214: 419-429

Trindade SC (2011). Nanotech biofuels and fuel additives. In: dos Santos Bernardes MA, editor. Biofuel's Engineering Process Technology. Rijeka, Croatia: InTech; 103-114.

Tripathi D K, S Singh, S Singh, R Pandey, V P Singh, N C. Sharma, S M Prasad, N K Dubey, D K Chauhan (2017). An overview on manufactured nanoparticles in plants: Uptake, translocation, accumulation and phytotoxicity. Plant Physiology and Biochemistry, 110: 2-12.

Ulrichs C, Mewis I, Goswami A (2005). Crop diversification aiming nutritional security in West Bengal: biotechnology of stinging capsules in nature's water-blooms. Ann Tech Issue of State Agri Technologists Service Assoc; 1-18.

Umarani, R. and Mala, R (2013). Influence of Calcium Phosphate Nano Gel Fertilizer Composite on Enzymes, Biomolecules and Yield of Abelmoschus esculentus. International Journal of Agriculture, Environment \& Biotechnology, 6: 771-777.

Valenstein JS (2012). Developing Nanotechnology for Biofuel and Plant Science Applications [Doctoral Thesis]. Ames, IA: Iowa State University; Available from: http://lib.dr.iastate.edu/etd/12493.

Vinutha JS, Bhagat D, Bakthavatsalam N (2013). Nanotechnology in the management of polyphagous pest Helicoverpa armigera. J Acad Indus Res. 1(10): 606-608.

Vítková M, S Rákosová, Z Michálková, M Komárek (2017). Metal(loid)s behaviour in soils amended with nano zero-valent iron as a function of $\mathrm{pH}$ and time. Journal of Environmental Management, 186 (Part 2): 268-276.

Wan N., X Ji, J Jiang, H Qiao, K Huang (2013). A methodological approach to assess the combined reduction of chemical pesticides and chemical fertilizers for low-carbon agriculture. Ecological Indicators, 24: 344-352

Wanekaya AK, Chen W, Myung NV, Mulchandani A (2006). Nanowire-based electrochemical 
biosensors. Electroanalysis; 18(6): 533-550.

Wang C, R. He, Y Wu, M Lürling, H Cai, H-L Jiang, X Liu (2017). Bioavailable phosphorus $(P)$ reduction is less than mobile $\mathrm{P}$ immobilization in lake sediment for eutrophication control by inactivating agents. Water Research, 109: 196-206

Wang P, E Lombi, F-J Zhao, P M. Kopittke (2016). Nanotechnology: A New Opportunity in Plant Sciences. Trends in Plant Science, 21 (8): 699-712.

Wang X., D Zhang, X Pan, D-J Lee, F A. Al-Misned, M. G Mortuza, G M Gadd (2017). Aerobic and anaerobic biosynthesis of nano-selenium for remediation of mercury contaminated soil. Chemosphere, 170: 266-273

Wang Y., B Z Chen, Y J Liu, Z M Wu, X D Guo (2017). Application of mesoscale simulation to explore the aggregate morphology of $\mathrm{pH}$-sensitive nanoparticles used as the oral drug delivery carriers under different conditions. Colloids and Surfaces B: Biointerfaces, 151: 280-286

Wang Y-J, M Larsson, W-T Huang, S-H Chiou, S J. Nicholls, J-I Chao, D-M Liu (2016). The use of polymer-based nanoparticles and nanostructured materials in treatment and diagnosis of cardiovascular diseases: Recent advances and emerging designs. Progress in Polymer Science, 57: $153-178$

Warheit DB (2008). How meaningful are the results of nanotoxicity studies in the absence of adequate material characterization? Toxicological Sciences, 101: 183-185.

Watson J-L, T Fang, C. O. Dimkpa, D. W. Britt, J. E. McLean, A. Jacobson and A. J. Anderson (2015). The phytotoxicity of $\mathrm{ZnO}$ nanoparticles on wheat varies with soil properties. Biometals 28:101-112. DOI: $10.1007 / \mathrm{s} 10534-014-9806-8$

Wu J., Y Xie, Z Fang, W Cheng, P E Tsang (2016). Effects of $\mathrm{Ni} / \mathrm{Fe}$ bimetallic nanoparticles on phytotoxicity and translocation of polybrominated diphenyl ethers in contaminated soil. Chemosphere, 162: $235-242$

Xie Y, Li B, Zhang Q, Zhang C, Lu K and Tao G (2011). Effects of nano-TiO2 on photosynthetic characteristics of Indocalamus barbatus. $J$ Northeast for Univ, 39: 22-25.

Xue X, R Cheng, L Shi, Z Ma and X Zheng (2016). Nanomaterials for Monitoring and Remediation of Water Pollution. In: S. Ranjan et al. (eds.), Nanoscience in Food and Agriculture 2, Sustainable
Agriculture Reviews 21, DOI: 10.1007/978-3-31939306-3_6, Springer International Publishing Switzerland

Yang Y-F, Y-H Cheng, C-M Liao (2016). In situ remediation-released zero-valent iron nanoparticles impair soil ecosystems health: A C. elegans biomarker-based risk assessment. Journal of Hazardous Materials, 317: 210-220

Yang Z, Z Fang, L Zheng, W Cheng, P E Tsang, J Fang, D Zhao (2016). Remediation of lead contaminated soil by biochar-supported nano-hydroxyapatite. Ecotoxicology and Environmental Safety, 132: 224230

Yotova L, Yaneva S, Marinkova D (2013). Biomimetic nanosensors for determination of toxic compounds in food and agricultural products (review). Journal of Chemical Technology and Metallurgy; 48(3): 215-227.

Zak D, N Meyer, Alvaro Cabezas, Jörg Gelbrecht, Rüdiger Mauersberger, Bärbel Tiemeyer, Carola Wagner, Rob McInnes (2015). Topsoil removal to minimize internal eutrophication in rewetted peatlands and to protect downstream systems against phosphorus pollution: A case study from NE Germany. Ecological Engineering, http:// dx.doi.org/10.1016/j.ecoleng.2015.12.030

Zhang X. and V V Vesselinov (2017). Integrated modeling approach for optimal management of water, energy and food security nexus. Advances in Water Resources, 101: 1-10

Zhang K, Z Pei, D Wang (2016). Organic solvent pretreatment of lignocellulosic biomass for biofuels and biochemicals: A review. Bioresource Technology, 199: 21-33.

Zhang W, Y Dan, H Shi, X Ma (2017). Elucidating the mechanisms for plant uptake and in-planta speciation of cerium in radish (Raphanus sativus L.) treated with cerium oxide nanoparticles. Journal of Environmental Chemical Engineering, 5 (1): $572-577$

Zhang X, J. Liang and S. Ding (2014). The Application of Nanostructure MoS2 Materials in Energy Storage and Conversion. In: Z. M. Wang (ed.), MoS2, Lecture Notes in Nanoscale Science and Technology 21, pp: 237 - 268. DOI: 10.1007/978-3319-02850-7_9, Springer International Publishing Switzerland

Zhang X, X Zhang, B Yang, J Hui, M Liu, Z Chi, S. Liu, J. Xu and Y. Wei (2014b). Facile preparation

Env. Biodiv. Soil Security Vol. 3 (2019) 
and cell imaging applications of fluorescent organic nanoparticles that combine AIE dye and ringopening polymerization. Polymer Chemistry, 5: 318-322.

Zhang X, X Zhang, B Yang, Y Zhang, Y Wei (2014a). A new class of red fluorescent organic nanoparticles: Noncovalent fabrication and cell imaging applications. ACS Applied Materials \& Interfaces, 6: $3600-3606$.

Zhao L, Y Huang, C Hannah-Bick, A N. Fulton, A A. Keller (2016). Application of metabolomics to assess the impact of $\mathrm{Cu}(\mathrm{OH}) 2$ nanopesticide on the nutritional value of lettuce (Lactuca sativa): Enhanced $\mathrm{Cu}$ intake and reduced antioxidants. Nano Impact (3-4): 58-66

Zhao X, W Liu, Z Cai, B Han, T Qian, D Zhao (2016). An overview of preparation and applications of stabilized zero-valent iron nanoparticles for soil and ground water remediation. Water Research, 100: $245-266$

Zuverza-Mena N., D Martínez-Fernández, W Du, J A. Hernandez-Viezcas, N Bonilla-Bird, M L. LópezMoreno, M Komárek, J R. Peralta-Videa, J L. Gardea-Torresdey (2017). Exposure of engineered nanomaterials to plants: Insights into the physiological and biochemical responses-A review. Plant Physiology and Biochemistry, 110: 236-264.

(Received 21/1/2019; accepted 3/3/2019) 